\title{
High-Throughput Computational Screening of Cubic Perovskites for Solid Oxide Fuel Cell Cathodes
}

Ilker Tezsevin ${ }^{a, b, c}$, Mauritius C. M. van de Sanden ${ }^{a, c}$, Süleyman Er ${ }^{a, b,{ }^{*}}$

${ }^{a}$ DIFFER - Dutch Institute for Fundamental Energy Research, De Zaale 20, 5612 AJ Eindhoven, The Netherlands

${ }^{\mathrm{b}}$ CCER - Center for Computational Energy Research, De Zaale 20, 5612 AJ Eindhoven, The Netherlands

${ }^{\mathrm{c}}$ Department of Applied Physics, Eindhoven University of Technology, P.O. Box 513, $5600 \mathrm{MB}$ Eindhoven, The Netherlands

* Corresponding Author, e-mail: s.er@differ.nl 


\section{ABSTRACT}

It is a present-day challenge to design and develop oxygen permeable solid oxide fuel cell (SOFC) electrode and electrolyte materials that operate at low temperatures. Herein, by performing highthroughput density functional theory (HT-DFT) calculations, oxygen vacancy formation energy,

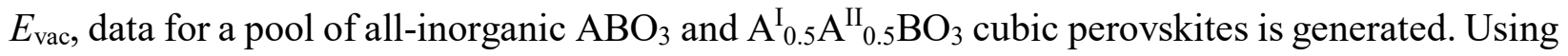
$E_{\text {vac }}$ data of perovskites, the area-specific resistance $(A S R)$ data, which is related to both oxygen reduction reaction activity and selective oxygen ion conductivity of materials, is calculated. Screening a total of 270 chemical compositions, 31 perovskites are identified as candidates with properties that are in between state-of-the-art SOFC cathode and oxygen permeation components. In addition, an intuitive approach to estimate $E_{\mathrm{vac}}$ and $A S R$ data of complex perovskites solely by using the easy-to-access data of simple perovskites is shown, which is expected to boost future explorations on perovskite material search space for genuinely diverse energy applications.

\section{TOC Graphic}

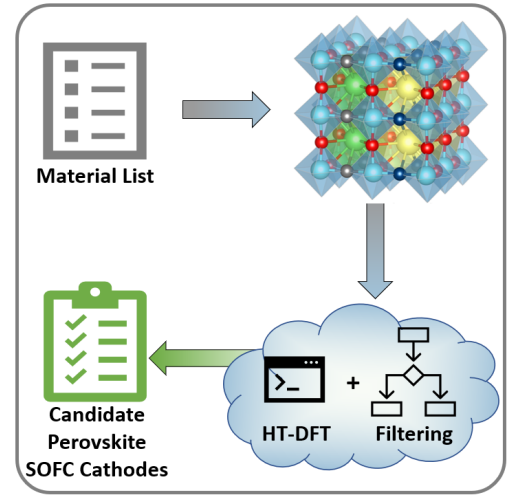


Technological advances are needed to address the rising demand for clean energy. ${ }^{1}$ Perovskites, represented with a basic formula of $\mathrm{ABO}_{3}$, attract considerable attention due to their tunable structure-composition-property relationships that facilitate their scalable use as active materials in various energy applications. ${ }^{2,3}$ In addition to catalytic and photovoltaic applications, perovskites are increasingly being more employed as active electrode and electrolyte materials for efficient conversion of clean energy in SOFCs. This is mainly due to their promising features including, stability, electronic conductivity, and oxygen ion permeability. ${ }^{3-10}$ However, to efficiently operate, typical SOFCs require very high temperatures $\left(T=700 \sim 1000^{\circ} \mathrm{C}\right)$. Enabling the operation at low temperatures, thereupon improving the overall energy efficiency of SOFCs, is a present-day challenge. ${ }^{10-14} \mathrm{La}_{1-x} \mathrm{Sr}_{x} \mathrm{MnO}_{3-\delta}$ (LSM) and $\mathrm{La}_{1-x} \mathrm{Sr}_{x} \mathrm{Co}_{1-y} \mathrm{Fe}_{y} \mathrm{O}_{3-\delta}$ (LSCF) are two families of perovskites that are widely used as cathode materials in SOFCs. The former is a broadly studied SOFC cathode material, whereas the latter is a more recently investigated perovskite for SOFCs. Recent research shows that LSCF offers a good compromise between oxygen transport and thermomechanical features, thereby capacitating its operation at relatively lower temperatures than LSM. ${ }^{12,13,15-17}$ A third perovskite SOFC electrode material that attracted recent research interest is $\mathrm{Ba}_{0.5} \mathrm{Sr}_{0.5} \mathrm{Co}_{0.75} \mathrm{Fe}_{0.25} \mathrm{O}_{3-\delta}$ (BSCF), which shows both superior oxygen permeation and power density at low temperature. ${ }^{11,13,15,18}$ However, BSCF suffers from material stability issues that adversely affect its practical use in SOFC applications. ${ }^{15,19,20}$ This study aims to find perovskites with promising SOFC electrode material features that are predicted to be in between the two stateof-the-art materials of LSCF and BSCF.

In addition to good electrical conductivity, SOFC cathode materials should feature both an active reduction of oxygen molecules on their surfaces and a fast transport of oxygen atoms through their bulk structures. ${ }^{21-23}$ The oxygen vacancy formation energy, $E_{\mathrm{vac}}$, of perovskites is a multi-purpose 
descriptor that is extensively used for estimating the stability of compounds and their applicationspecific behaviors. ${ }^{6,22,24,25}$ In recent studies, $E_{\mathrm{vac}}$ is used as a performance descriptor for highly diverse chemical reactions including, carbon dioxide reduction ${ }^{3,26,27}$, hydrogen evolution ${ }^{6,28,29}$, nitrous oxide reduction ${ }^{6,30}$, volatile organic compound oxidation ${ }^{3,6}$, oxygen reduction ${ }^{3,6,29,31,32}$, and in addition to all these, for oxygen ion diffusion through materials. ${ }^{22,33}$

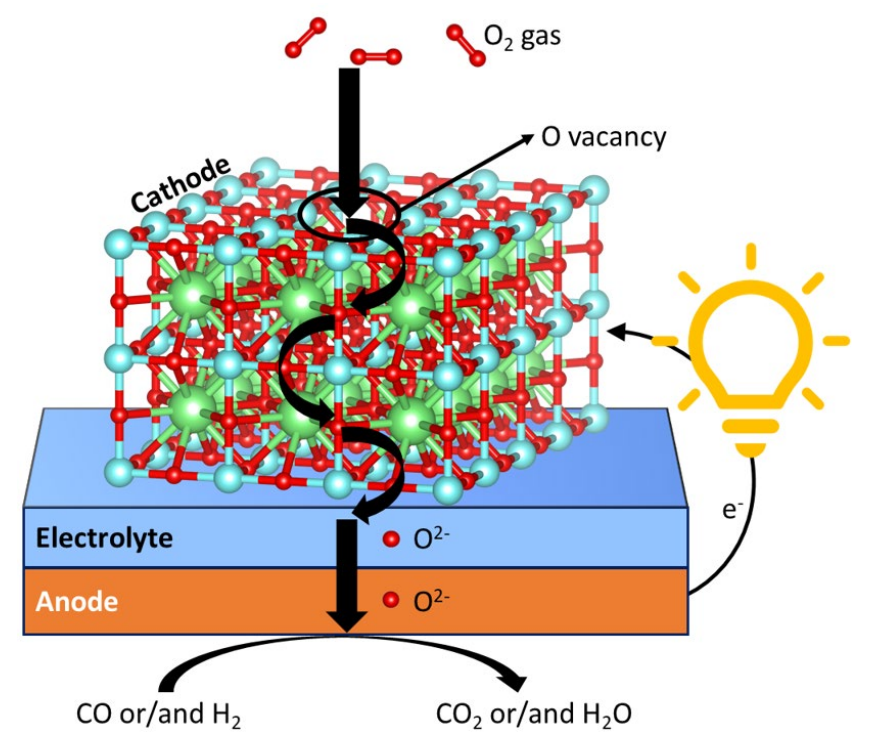

Figure 1. A schematic representation of oxygen utilization in SOFCs. Only the perovskite structure of the cathode material is depicted. Oxygen atoms are shown with red, A-type perovskite atoms with green, and B-type perovskite atoms with blue colored spheres.

The catalytic behavior and oxygen permeation performance of perovskites are influenced by the presence of oxygen atom vacancies in their structures. ${ }^{22,34}$ Figure 1 shows the adsorption of oxygen molecules on the surface of a SOFC cathode material and their subsequent reduction to oxygen ions. The newly generated oxygen atoms successively fill the vacant sites of the electrode. Similarly, oxygen is triggered to move from a high chemical potential cathode unit to a low 
chemical potential anode unit through a solid electrolyte. The oxidation of fuel (e.g. CO and/or $\mathrm{H}_{2}$ ) then takes place on the surface of SOFC anode material. ${ }^{16}$ Therefore, the convenience of perovskites for atomic-scale migrations of oxygen atoms, or similarly for oxygen atom vacancies in the opposite direction, relates to their macroscale oxygen transfer performance. ${ }^{7,35}$ In addition to this, recent experimental works on perovskites attribute the high performance of oxygen exchange to low $A S R \cdot{ }^{9,13,14}$ Hence, to estimate the SOFC performance, developing a calculable relationship between $E_{\mathrm{vac}}$ and $A S R$ data of perovskite-based materials is useful. Typically, the oxygen atom vacancies in perovskites facilitate a fast diffusion of oxygen ions. However, a too strong tendency for $\mathrm{O}$ vacancy formation, as evident from a largely negative $E_{\mathrm{vac}}$, creates a risk for the structural integrity of the compound. ${ }^{3}$ Therefore, in addition to its exercise as a descriptor for the catalytic behavior and the oxygen transport performance of materials, $E_{\mathrm{vac}}$ is also useful when estimating the stability of perovskites.

Herein, a group of cubic perovskites is systematically explored for their esteemed use as low temperature SOFC cathode materials. First, based on the knowledge of existing compounds, a relation between the measured $A S R$ and the computed $E_{\text {vac }}$ data is formulated. Next, a virtual chemical library of perovskites, which contains $108 \mathrm{ABO}_{3}$ and $162 \mathrm{~A}_{0.5}^{\mathrm{I}} \mathrm{A}_{0.5}^{\mathrm{II}} \mathrm{BO}_{3}$ perovskites, is enumerated. Then, for all the compounds in the library, the $E_{\mathrm{vac}}$ data is generated by applying HTDFT calculations. After that, the $A S R$ data of a total of 270 virtual materials is estimated by using the newly developed relationship between $E_{\text {vac }}$ and $A S R$ of experimentally investigated materials and the DFT calculated $E_{\mathrm{vac}}$ data. Finally, the most promising candidate materials for SOFC cathodes are singled out and a practical means for accessing the key $E_{\mathrm{vac}}$ and $A S R$ data of complex perovskites is presented. The specific aspects of the stages of the study are described below. 


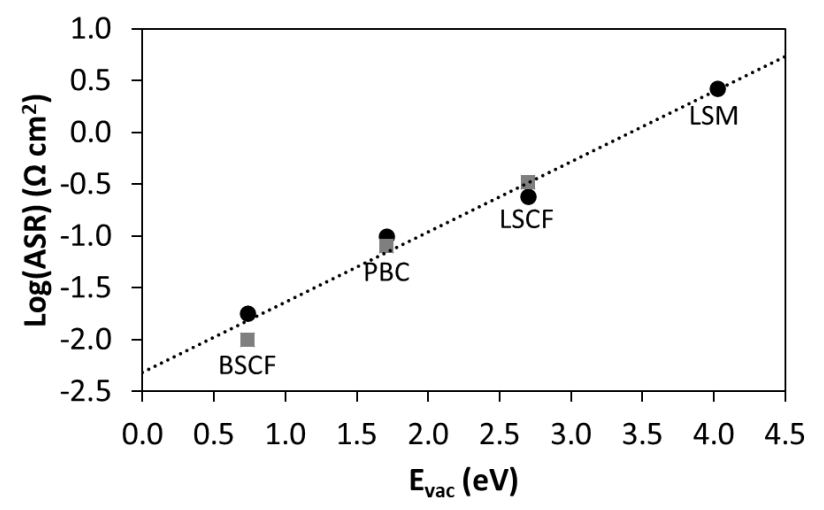

Figure 2. LR between the measured $A S R$ and the calculated $E_{\text {vac }}$ data: $\bullet$ dataset is plotted using the available data of materials on GDC and $\mathbf{d}$ dataset is plotted using the available data of materials on SDC substrates. All data points are used in the LR model.

First, a direct correlation between $E_{\mathrm{vac}}$ and the $\log (A S R)$ is developed by using the experimental data of $\quad \operatorname{Pr}_{0.5} \mathrm{Ba}_{0.5} \mathrm{CoO}_{3-\delta} \quad(\mathrm{PBC}), \quad \mathrm{La}_{0.8} \mathrm{Sr}_{0.2} \mathrm{MnO}_{3-\delta}, \quad \mathrm{Ba}_{0.5} \mathrm{Sr}_{0.5} \mathrm{Co}_{0.8} \mathrm{Fe}_{0.2} \mathrm{O}_{3-\delta}, \quad$ and $\mathrm{La}_{0.6} \mathrm{Sr}_{0.4} \mathrm{Co}_{0.2} \mathrm{Fe}_{0.8} \mathrm{O}_{3-\delta}$ perovskites on Gd-doped ceria (GDC) and $\mathrm{Ba}_{0.5} \mathrm{Sr}_{0.5} \mathrm{Co}_{0.8} \mathrm{Fe}_{0.2} \mathrm{O}_{3-\delta}$, $\operatorname{Pr}_{0.5} \mathrm{Ba}_{0.5} \mathrm{CoO}_{3-\delta}$, and $\mathrm{La}_{0.6} \mathrm{Sr}_{0.4} \mathrm{Co}_{0.2} \mathrm{Fe}_{0.8} \mathrm{O}_{3-\delta}$ perovskites on $\mathrm{Sm}$-doped ceria (SDC) substrates. ${ }^{36-}$ 42 To virtually match these experimented compositions, cubic supercells of $\mathrm{Pr}_{4} \mathrm{Ba}_{4} \mathrm{Co}_{8} \mathrm{O}_{24}$, $\mathrm{La}_{6} \mathrm{Sr}_{2} \mathrm{Mn}_{8} \mathrm{O}_{24}, \quad \mathrm{Ba}_{4} \mathrm{Sr}_{4} \mathrm{Co}_{6} \mathrm{FeO}_{24}$, and $\mathrm{La}_{5} \mathrm{Sr}_{3} \mathrm{Co}_{2} \mathrm{Fe}_{6} \mathrm{O}_{24}$, which respectively represent, $\operatorname{Pr}_{0.5} \mathrm{Ba}_{0.5} \mathrm{CoO}_{3}, \quad \mathrm{La}_{0.75} \mathrm{Sr}_{0.25} \mathrm{MnO}_{3}, \quad \mathrm{Ba}_{0.5} \mathrm{Sr}_{0.5} \mathrm{Co}_{0.75} \mathrm{Fe}_{0.25} \mathrm{O}_{3}, \quad$ and $\quad \mathrm{La}_{0.625} \mathrm{Sr}_{0.375} \mathrm{Co}_{0.25} \mathrm{Fe}_{0.75} \mathrm{O}_{3}$ compositions, are used in DFT calculations. It is known that perovskites that have non-cubic symmetry at room temperature are usually prone to a phase transformation to cubic symmetry at higher temperatures., ${ }^{2,43}$ For example, $\mathrm{BaTiO}_{3}$ has rhombohedral $(R 3 m)$ symmetry at low temperature, and upon heating, its structure transforms to orthorhombic $(A m m 2)$ at $-90{ }^{\circ} \mathrm{C}$, to tetragonal $(P 4 m m)$ at $5{ }^{\circ} \mathrm{C}$, and finally to cubic $(P m 3 m)$ at above $120{ }^{\circ} \mathrm{C} .{ }^{44}$ Therefore, as a pragmatic reasoning owing to SOFC operation temperatures, all structures considered here are 
assumed in cubic symmetry. Also, notably, the weighted average vacancy formation energies are calculated by performing DFT simulations on all of the unique oxygen vacant configurations of perovskite structures. Accordingly, as shown in Figure 2, a linear regression (LR) model is developed for the measured $\log (A S R)$ and the DFT calculated $E_{\text {vac }}$ data of materials. The obtained LR equation

$$
\log (A S R)=0.68\left(E_{\mathrm{vac}}\right)-2.32
$$

Eq. 1

with $\mathrm{R}^{2}=0.98$, shows a large positive linear association, although the data in experiments were collected by using different, GDC and SDC, substrates.

a)

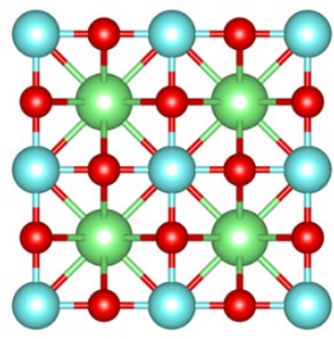

Top View

b)

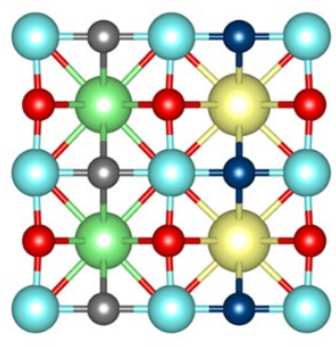

Top View

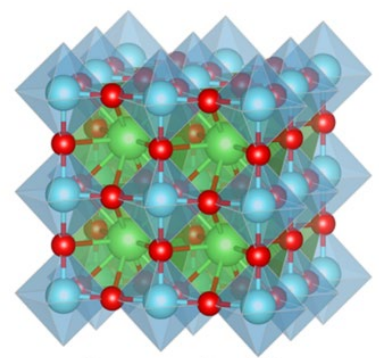

Perspective View

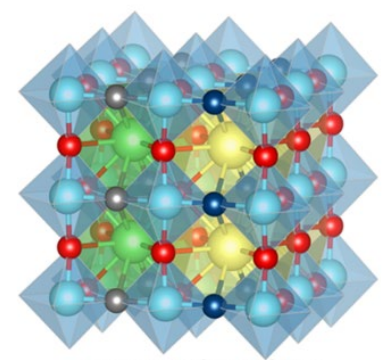

Perspective View

Figure 3. Top and perspective views of a) $\mathrm{A}_{8} \mathrm{~B}_{8} \mathrm{O}_{24}$ and b) $\mathrm{A}_{4}^{\mathrm{I}} \mathrm{A}^{\mathrm{II}}{ }_{4} \mathrm{~B}_{8} \mathrm{O}_{24}$ supercells that represent $\mathrm{ABO}_{3}$ and $\mathrm{A}_{0.5}^{\mathrm{I}} \mathrm{A}^{\mathrm{II}}{ }_{0.5} \mathrm{BO}_{3}$ group of perovskites, respectively. Green and yellow spheres represent A-type (i.e., $\mathrm{A}, \mathrm{A}^{\mathrm{I}}$, or $\mathrm{A}^{\mathrm{II}}$ ) metal cations, blue spheres represent B-type metal cations, and red 
spheres represent $\mathrm{O}$ atoms. In $\mathrm{A}_{4}^{\mathrm{I}} \mathrm{A}_{4}{ }_{4}{ }_{3} \mathrm{~B}_{8} \mathrm{O}_{24}$ supercells, as shown in $\mathbf{b}$ ), $\mathrm{O}$ atoms are categorized into three different groups in relation to their coordination to first order neighboring metal atoms. For an improved visual perception, these different groups of $\mathrm{O}$ atoms are shown with red, grey, and dark blue spheres.

In the next stage, HT-DFT calculations are employed for building the $E_{\mathrm{vac}}$ data for a virtual chemical library of $\mathrm{ABO}_{3}$ and $\mathrm{A}_{0.5}^{\mathrm{I}} \mathrm{A}_{0.5}^{\mathrm{II}} \mathrm{BO}_{3}$ family of perovskites. As shown in Figure $3, \mathrm{ABO}_{3}$ perovskites have a single group of unique coordination arrangement for all their oxygen atoms, whereas $\mathrm{A}_{0.5}^{\mathrm{I}} \mathrm{A}_{0.5}^{\mathrm{II}} \mathrm{BO}_{3}$ perovskites have three groups of unique oxygens. In the latter situation, from a total of 24 oxygen atoms in an $\mathrm{A}_{4}^{\mathrm{I}} \mathrm{A}^{\mathrm{II}}{ }_{4} \mathrm{~B}_{8} \mathrm{O}_{24}$ supercell shown in Figure 3.b, four oxygen atoms (grey spheres) interact with $\mathrm{A}^{\mathrm{I}}$ - and B-type metal cations, four oxygen atoms (dark blue spheres) interact with $\mathrm{A}^{\mathrm{II}}$ - and B-type metal cations, and 16 oxygen atoms (red spheres) interact with all of the $\mathrm{A}^{\mathrm{I}}-$, $\mathrm{A}^{\mathrm{II}}$-, and B-type metal cations. Therefore, separate DFT calculations are performed to sample all possible $\mathrm{O}$ vacant positions in $\mathrm{A}_{4}^{\mathrm{I}} \mathrm{A}_{4}^{\mathrm{II}} \mathrm{B}_{8} \mathrm{O}_{23}$ supercells. This way, the weighted average oxygen formation energies are calculated for $\mathrm{A}_{0.5}^{\mathrm{I}} \mathrm{A}_{0.5}^{\mathrm{II}} \mathrm{BO}_{3}$ perovskites.

The optimized lattice parameters and calculated $E_{\mathrm{vac}}$ data of perovskites are shown in Supporting Information Figure $\mathrm{S} 1$ and $\mathrm{S} 2$, respectively. For $\mathrm{ABO}_{3}$ perovskites with $\mathrm{B}$-type metal cations that are chosen from the same row of the periodic table, an increase in atomic number results in a decrease in $E_{\text {vac }}$ (Figure S2.a). Thus, irrespective of the A-type cation used in the simple perovskites, the minimum $E_{\mathrm{vac}}$ values are always achieved by using B-type atoms from group 12 . Likewise, the $E_{\text {vac }}$ data of $\mathrm{A}_{0.5}^{\mathrm{I}} \mathrm{A}_{0.5}^{\mathrm{II}} \mathrm{BO}_{3}$ perovskites (Figure S2.b) are calculated by considering all possible combinations of A-type cations, where $\mathrm{A}=\mathrm{La}, \mathrm{Ba}, \mathrm{Sr}$, and $\mathrm{Ca}$. Similar to simple 
perovskites, for $\mathrm{A}_{0.5}^{\mathrm{I}} \mathrm{A}_{0.5}^{\mathrm{II}} \mathrm{BO}_{3}$ perovskites the $E_{\text {vac }}$ decreases when B-type cations of increasing atomic numbers are used from the same row of the periodic table.

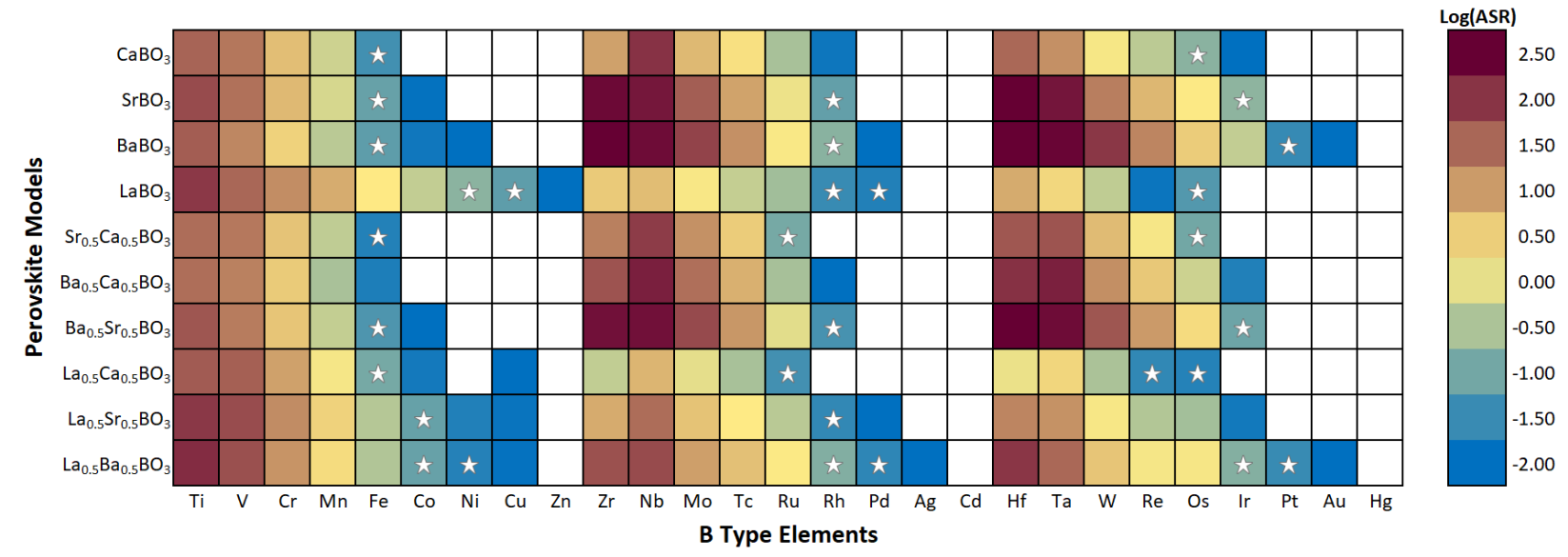

Figure 4. A heat map of perovskites' $\log (A S R)$ data. The most promising compounds are indicated by using a star sign, whereas the likely unstable perovskites are shown with blank cells.

To identify candidate materials for SOFC cathodes, $A S R$ extrema values are chosen based on the available information on top-performing perovskite-based SOFC electrode materials, BSCF (ASR $\left.=0.02 \Omega \mathrm{cm}^{2}\right)^{37}$ and LSCF $\left(A S R=0.24 \Omega \mathrm{cm}^{2}\right)^{42}$. The $\log (A S R)$ data of the virtual materials that were estimated by using the LR model shown in Equation 1 are provided in Figure S3. Additionally, a heatmap of the $\log (A S R)$ data of the likely stable perovskites is shown in Figure 4. Additionally, the most promising SOFC cathode materials, which have calculated properties that are in between BSCF and LSCF, are highlighted in Figure 4. From a pool of 270 perovskites investigated in the current study, 31 are shortlisted as candidate SOFC cathode materials. Therefore, to inspect the electrically conductive nature of candidate materials, electronic density of states (DOS) calculations are performed on the optimized structures of perovskites (Figures S5S8). No apparent electronic band gaps are identified in the DOS analysis of DFT/PBE calculated 
results (Figures S5 and S6). Thus, endorsing the use of these promising perovskites as electrodes. Withal, other important factors that are beyond the scope of this study, including the cost and abundance of constituting elements or the synthetic accessibility of materials, can be considered to scale down the list of candidates further. ${ }^{45}$
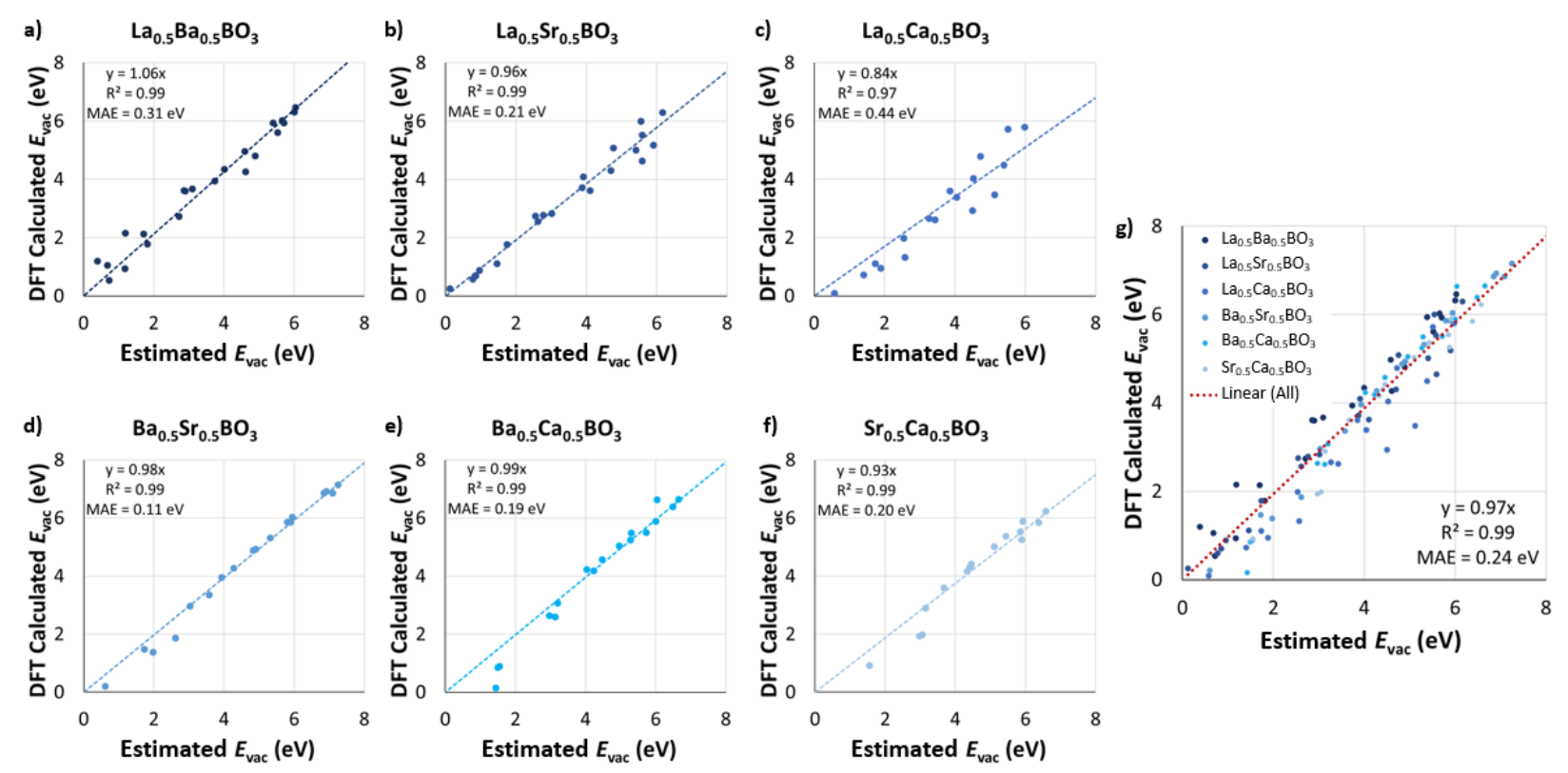

Figure 5. Comparison of DFT calculated and estimated $E_{\text {vac }}$ data of $\mathrm{A}_{0.5}^{\mathrm{I}} \mathrm{A}_{0.5}^{\mathrm{II}} \mathrm{BO}_{3}$ perovskites covered in this study. LR results are shown for a) $\mathrm{La}_{0.5} \mathrm{Ba}_{0.5} \mathrm{BO}_{3}$, b) $\mathrm{La}_{0.5} \mathrm{Sr}_{0.5} \mathrm{BO}_{3}$, c) $\mathrm{La}_{0.5} \mathrm{Ca}_{0.5} \mathrm{BO}_{3}$, d) $\mathrm{Ba}_{0.5} \mathrm{Sr}_{0.5} \mathrm{BO}_{3}$, e) $\mathrm{Ba}_{0.5} \mathrm{Ca}_{0.5} \mathrm{BO}_{3}$, f) $\mathrm{Sr}_{0.5} \mathrm{Ca}_{0.5} \mathrm{BO}_{3}$, and g) all $\mathrm{A}_{0.5}^{\mathrm{I}} \mathrm{A}_{0.5} \mathrm{II}_{3} \mathrm{BO}_{3}$ compounds. In here, only the likely stable candidate materials are conceded, and the complete data including also the likely unstable compounds is shown in Figure S4.

To help forward the material screening efforts on complex perovskites beyond the current work, a regression analysis is performed for investigating the relationships between the utterly DFT calculated and the estimated oxygen vacancy formation energy data of materials. For the latter, 
$E_{\text {vac }}^{\text {est }}$ of the comparably more complex, $\mathrm{A}_{0.5}^{\mathrm{I}} \mathrm{A}_{0.5}^{\mathrm{II}} \mathrm{BO}_{3}$ perovskites, are estimated by incorporating the DFT calculated $E_{\text {vac }}$ data of simple perovskites, $\mathrm{A}^{\mathrm{I}} \mathrm{BO}_{3}$ and $\mathrm{A}^{\mathrm{II}} \mathrm{BO}_{3}$, into the following equation

$$
E_{\mathrm{vac}}^{\text {est }}=x * E_{\mathrm{vac}}^{\mathrm{A}^{\mathrm{I}} \mathrm{BO}_{3}}+(1-x) * E_{\mathrm{vac}}^{\mathrm{A}^{\mathrm{I}} \mathrm{BO}_{3}} \quad \text { Eq.2 }
$$

where $x=0.5$ for the present material compositions. Figure 5 shows the observed correlations between the DFT calculated, $E_{\mathrm{vac}}$, and the estimated, $E_{\mathrm{vac}}^{\text {est }}$, data on a group of complex perovskites. In this analysis, $\mathrm{A}_{0.5}^{\mathrm{I}} \mathrm{A}_{0.5}{ }_{0.5} \mathrm{BO}_{3}$ perovskites with negative $E_{\text {vac }}$ data are omitted, since a negative $E_{\text {vac }}$ indicates that the assumed perovskite structure is likely unstable. As shown in Figure 5.a-f, for any complex perovskite constructed by a combination of A-type atoms, the calculated versus estimated data produce linear fits with $\mathrm{R}^{2}=0.97 \sim 0.99$. Figure 5.g shows the correlation between $E_{\mathrm{vac}}$ and $E_{\mathrm{vac}}^{\text {est }}$ for the merged data of all complex perovskites considered here, which yields an $\mathrm{R}^{2}$ and a mean absolute error (MAE) of 0.99 and $0.24 \mathrm{eV}$, respectively. To improve the precision of $E_{\mathrm{vac}}^{\text {est }}$ data, in comparison to the directly calculated DFT $E_{\text {vac }}$ data of $\mathrm{A}_{0.5}^{\mathrm{I}} \mathrm{A}^{\mathrm{II}}{ }_{0.5} \mathrm{BO}_{3}$ perovskites, using the following simple equation is recommended

$$
E_{\mathrm{vac}}=0.97\left(E_{\mathrm{vac}}^{\text {est }}\right) \quad \text { Eq.3 }
$$

Thus, by combining Equations 1-3, the following equation is obtained

$$
\log (A S R)=0.33\left[\left(E_{\mathrm{vac}}^{\mathrm{A}^{\mathrm{I}} \mathrm{BO}_{3}}+E_{\mathrm{vac}}^{\mathrm{A}^{\mathrm{II}} \mathrm{BO}_{3}}\right)\right]-2.32 \quad \text { Eq.4 }
$$


which allows for the estimation of $\log (A S R)$ data of $\mathrm{A}_{0.5}^{\mathrm{I}} \mathrm{A}_{0.5}^{\mathrm{II}} \mathrm{BO}_{3}$ perovskites directly from the computed oxygen vacancy formation energies of the simple perovskites.

In summary, by performing HT-DFT calculations on a virtual chemical library of $108 \mathrm{ABO}_{3}$ and $162 \mathrm{~A}_{0.5}^{\mathrm{I}} \mathrm{A}_{0.5}^{\mathrm{II}_{0}} \mathrm{BO}_{3}$ all-inorganic cubic perovskites, their potential use as electrode materials in SOFCs is scrutinized. $E_{\mathrm{vac}}$ and $A S R$ information of the compounds is used as principal chemical descriptors for evaluating the thermodynamic stability, catalytic behavior, and oxygen ion permeation performance of the newly generated virtual materials. A total of 31 candidate perovskites are predicted to show properties that are in between the two state-of-the-art SOFC active materials of BSCF and LSCF. Additionally, the complex perovskites showed markedly linear $E_{\mathrm{vac}}$ profiles against their ancestral simple perovskite data. Thus, with an attempt to expedite future in silico and in lab explorations on the vast chemical space of candidate perovskites, a screening strategy that relies on deriving $E_{\text {vac }}$ and $A S R$ data of complex $\mathrm{A}_{0.5}^{\mathrm{I}} \mathrm{A}_{0.5}{ }_{0.5} \mathrm{BO}_{3}$ perovskites directly from the data of simple $\mathrm{A}^{\mathrm{I}} \mathrm{BO}_{3}$ and $\mathrm{A}^{\mathrm{II}} \mathrm{BO}_{3}$ perovskites is propounded. 


\title{
ASSOCIATED CONTENT
}

Supporting Information Available: Optimized lattice parameters of structures, calculated oxygen vacancy formation energies, area-specific polarization resistance data, comparison of calculated and estimated $E_{\text {vac }}$ data for $\mathrm{A}^{\mathrm{I}}{ }_{0.5} \mathrm{~A}^{\mathrm{II}}{ }_{0.5} \mathrm{BO}_{3}$ perovskites considered in this study, density of states plots, and computational methodology.

\author{
AUTHOR INFORMATION \\ * Corresponding Author \\ E-mail: s.er@differ.nl \\ Website: https://www.amdlab.nl
}

\section{Notes}

The authors declare no competing financial interest.

\section{ACKNOWLEDGMENTS}

The work presented in this paper is part of the European project KEROGREEN, which has received funding from the European Union's Horizon 2020 Research and Innovation Programme under Grant Agreement no 763909. SE acknowledges funding from the initiative "Computational Sciences for Energy Research" of Shell and the Netherlands Organization for Scientific Research (NWO) grant no 15CSTT05. This work was sponsored by NWO Exact and Natural Sciences for the use of supercomputer facilities. 


\section{REFERENCES}

(1) Tezsevin, I.; van de Sanden, M. C. M.; Er, S. Surface Charging Activated Mechanism Change: A Computational Study of $\mathrm{O}, \mathrm{CO}$, and $\mathrm{CO} 2$ Interactions on Ag Electrodes. $J$. Energy Chem. 2020, 50, 307-313.

(2) Sebastian, M. T. $\mathrm{ABO}_{3}$ Type Perovskites. In Dielectric Materials for Wireless Communication; Elsevier, 2008; 161-203.

(3) Hwang, J.; Rao, R. R.; Giordano, L.; Katayama, Y.; Yu, Y.; Shao-Horn, Y. Perovskites in Catalysis and Electrocatalysis. Science. 2017, 358, 751-756.

(4) Labhasetwar, N.; Saravanan, G.; Kumar Megarajan, S.; Manwar, N.; Khobragade, R.; Doggali, P.; Grasset, F. Perovskite-Type Catalytic Materials for Environmental Applications. Sci. Technol. Adv. Mater. 2015, 16, 036002.

(5) Tyunina, M.; Yao, L.; Chvostova, D.; Dejneka, A.; Kocourek, T.; Jelinek, M.; Trepakov, V.; van Dijken, S. Concurrent Bandgap Narrowing and Polarization Enhancement in Epitaxial Ferroelectric Nanofilms. Sci. Technol. Adv. Mater. 2015, 16, 026002.

(6) R. J. H. Voorhoeve; D. W. Johnson Jr.; J. P. Remeika; P. K. Gallagher. Perovskite Oxides: Materials Science in Catalysis. Science. 1977, 195, 827-833.

(7) Himma, N. F.; Wardani, A. K.; Prasetya, N.; Aryanti, P. T. P.; Wenten, I. G. Recent Progress and Challenges in Membrane-Based $\mathrm{O}_{2} / \mathrm{N}_{2}$ Separation. Rev. Chem. Eng. 2019, 35, 591-625.

(8) Kubicek, M.; Bork, A. H.; Rupp, J. L. M. Perovskite Oxides-a Review on a Versatile Material Class for Solar-to-Fuel Conversion Processes. J. Mater. Chem. A 2017, 5, 1198312000.

(9) Gómez, S. Y.; Hotza, D. Current Developments in Reversible Solid Oxide Fuel Cells. Renewable and Sustainable Energy Reviews. Elsevier 2016, 155-174. 
(10) Muñoz-García, A. B.; Ritzmann, A. M.; Pavone, M.; Keith, J. A.; Carter, E. A. Oxygen Transport in Perovskite-Type Solid Oxide Fuel Cell Materials: Insights from Quantum Mechanics. Acc. Chem. Res. 2014, 47, 3340-3348.

(11) Duan, C.; Hook, D.; Chen, Y.; Tong, J.; O’Hayre, R. Zr and Y Co-Doped Perovskite as a Stable, High Performance Cathode for Solid Oxide Fuel Cells Operating below $500^{\circ} \mathrm{C}$. Energy Environ. Sci. 2017, 10, 176-182.

(12) Ritzmann, A. M.; Muñoz-García, A. B.; Pavone, M.; Keith, J. A.; Carter, E. A. Ab Initio Evaluation of Oxygen Diffusivity in $\mathrm{LaFeO}_{3}$ : The Role of Lanthanum Vacancies. MRS Commun. 2013, 3, 161-166.

(13) Li, L.; Yang, H.; Gao, Z.; Zhang, Y.; Dong, F.; Yang, G.; Ni, M.; Lin, Z. Nickel-Substituted $\mathrm{Ba}_{0.5} \mathrm{Sr}_{0.5} \mathrm{Co}_{0.8} \mathrm{Fe}_{0.2} \mathrm{O}_{3-\delta}$ : A Highly Active Perovskite Oxygen Electrode for ReducedTemperature Solid Oxide Fuel Cells. J. Mater. Chem. A 2019, 7, 12343-12349.

(14) He, W.; Wu, X.; Yang, G.; Shi, H.; Dong, F.; Ni, M. $\mathrm{BaCo}_{0.7} \mathrm{Fe}_{0.22} \mathrm{Y}_{0.08} \mathrm{O}_{3-\delta}$ as an Active Oxygen Reduction Electrocatalyst for Low-Temperature Solid Oxide Fuel Cells below 600 ${ }^{\circ} \mathrm{C}$. ACS Energy Lett. 2017, 2, 301-305.

(15) Kotomin, E. A.; Mastrikov, Y. A.; Kuklja, M. M.; Merkle, R.; Roytburd, A.; Maier, J. First Principles Calculations of Oxygen Vacancy Formation and Migration in Mixed Conducting $\mathrm{Ba}_{0.5} \mathrm{Sr}_{0.5} \mathrm{Co}_{1-\mathrm{y}} \mathrm{Fe}_{\mathrm{y}} \mathrm{O}_{3-\delta}$ Perovskites. Solid State Ionics 2011, 188, 1-5.

(16) Lee, Y.-L.; Morgan, D. Prediction of Surface Oxygen Vacancy Concentrations of (La $\left.{ }_{\mathrm{x}} \mathrm{Sr}_{\mathrm{x}}\right) \mathrm{MnO}_{3}$. ECS Trans. 2019, 25, 2769-2774.

(17) Ovtar, S.; Søgaard, M.; Norrman, K.; Hendriksen, P. V. Oxygen Exchange and Transport in $\left(\mathrm{La}_{0.6} \mathrm{Sr}_{0.4}\right)_{0.98} \mathrm{FeO}_{3-\mathrm{d}}-\mathrm{Ce}_{0.9} \mathrm{Gd}_{0.1} \mathrm{O}_{1.95}$ Dual-Phase Composites. J. Electrochem. Soc. 2018 , 165, F220-F231. 
(18) Baumann, S.; Serra, J. M.; Lobera, M. P.; Escolástico, S.; Schulze-Küppers, F.; Meulenberg, W. A. Ultrahigh Oxygen Permeation Flux through Supported $\mathrm{Ba}_{0.5} \mathrm{Sr}_{0.5} \mathrm{Co}_{0.8} \mathrm{Fe}_{0.2} \mathrm{O}_{3-\delta}$ Membranes. J. Memb. Sci. 2011, 377, 198-205.

(19) Plazaola, A. A.; Labella, A. C.; Liu, Y.; Porras, N. B.; Tanaka, D. A. P.; Annaland, M. V. S.; Gallucci, F. Mixed Ionic-Electronic Conducting Membranes (MIEC) for Their Application in Membrane Reactors: A Review. Processes 2019, 7, 128.

(20) Kharton, V. V.; Yaremchenko, A. A.; Kovalevsky, A. V.; Viskup, A. P.; Naumovich, E. N.; Kerko, P. F. Perovskite-Type Oxides for High-Temperature Oxygen Separation Membranes. J. Memb. Sci. 1999, 163, 307-317.

(21) Uberuaga, B. P.; Pilania, G. Effect of Cation Ordering on Oxygen Vacancy Diffusion Pathways in Double Perovskites. Chem. Mater. 2015, 27, 5020-5026.

(22) Mayeshiba, T.; Morgan, D. Strain Effects on Oxygen Vacancy Formation Energy in Perovskites. Solid State Ionics 2017, 311, 105-117.

(23) Chen, G.; Buck, F.; Kistner, I.; Widenmeyer, M.; Schiestel, T.; Schulz, A.; Walker, M.; Weidenkaff, A. A Novel Plasma-Assisted Hollow Fiber Membrane Concept for Efficiently Separating Oxygen from CO in a $\mathrm{CO}_{2}$ Plasma. Chem. Eng. J. 2020, 392, 123699.

(24) Kim, C.; Eom, T.; Jee, M. S.; Jung, H.; Kim, H.; Min, B. K.; Hwang, Y. J. Insight into Electrochemical $\mathrm{CO}_{2}$ Reduction on Surface-Molecule-Mediated Ag Nanoparticles. ACS Catal. 2017, 7, 779-785.

(25) Emery, A. A.; Wolverton, C. High-Throughput DFT Calculations of Formation Energy, Stability and Oxygen Vacancy Formation Energy of $\mathrm{ABO}_{3}$ Perovskites. Sci. Data 2017, 4, $1-10$.

(26) Maiti, D.; Hare, B. J.; Daza, Y. A.; Ramos, A. E.; Kuhn, J. N.; Bhethanabotla, V. R. Earth 
Abundant Perovskite Oxides for Low Temperature CO2conversion. Energy Environ. Sci. 2018, 11, 648-659.

(27) Maiti, D.; Daza, Y. A.; Yung, M. M.; Kuhn, J. N.; Bhethanabotla, V. R. Oxygen Vacancy Formation Characteristics in the Bulk and across Different Surface Terminations of $\mathrm{La}_{(1-}$ ${ }_{\text {x) }} \mathrm{Sr}_{\mathrm{x}} \mathrm{Fe}_{(1-\mathrm{y})} \mathrm{Co}_{\mathrm{y}} \mathrm{O}_{(3-\delta)}$ Perovskite Oxides for $\mathrm{CO}_{2}$ conversion. J. Mater. Chem. A 2016, 4, $5137-5148$.

(28) Guan, D.; Zhou, J.; Huang, Y.-C.; Dong, C.-L.; Wang, J.-Q.; Zhou, W.; Shao, Z. Screening Highly Active Perovskites for Hydrogen-Evolving Reaction via Unifying Ionic Electronegativity Descriptor. Nat. Commun. 2019, 10.

(29) Montoya, J. H.; Doyle, A. D.; Nørskov, J. K.; Vojvodic, A. Trends in Adsorption of Electrocatalytic Water Splitting Intermediates on Cubic $\mathrm{ABO}_{3}$ Oxides. Phys. Chem. Chem. Phys. 2018, 20, 3813-3818.

(30) Beppu, K.; Hosokawa, S.; Asakura, H.; Teramura, K.; Tanaka, T. Role of Lattice Oxygen and Oxygen Vacancy Sites in Platinum Group Metal Catalysts Supported on $\mathrm{Sr}_{3} \mathrm{Fe}_{2} \mathrm{O}_{7-\delta}$ for NO-Selective Reduction. Catal. Sci. Technol. 2018, 8, 147-153.

(31) Cherkas, S. L.; Kalashnikov, V. L. A Solution of the Discrete Wheeler-Dewitt Equation in the Vicinity of Small Scale Factors and Quantum Mechanics in the Space of Negative Constant Curvature. Nonlinear Phenom. Complex Syst. 2014, 17, 358-363.

(32) Li, X.; Wang, H.; Cui, Z.; Li, Y.; Xin, S.; Zhou, J.; Long, Y.; Jin, C.; Goodenough, J. B. Exceptional Oxygen Evolution Reactivities on $\mathrm{CaCoO}_{3}$ and $\mathrm{SrCoO}_{3}$. Sci. $A d v$. 2019, 5, eaav6262.

(33) Lee, Y. L.; Kleis, J.; Rossmeisl, J.; Yang, S. H.; Morgan, D. Prediction of Solid Oxide Fuel Cell Cathode Activity with First-Principles Descriptors. Energy Environ. Sci. 2011, 4, 
$3966-3970$.

(34) Huang, W. L.; Zhu, Q.; Ge, W.; Li, H. Oxygen-Vacancy Formation in LaMO3 (M = Ti, V, Cr, Mn, Fe, Co, Ni) Calculated at Both GGA and GGA + U Levels. Comput. Mater. Sci. 2011, 50, 1800-1805.

(35) Zhang, L.; Liu, B.; Zhuang, H.; Kent, P. R. C.; Cooper, V. R.; Ganesh, P.; Xu, H. Oxygen Vacancy Diffusion in Bulk $\mathrm{SrTiO}_{3}$ from Density Functional Theory Calculations. Comput. Mater. Sci. 2016, 118, 309-315.

(36) Shao, Z.; Haile, S. M. A High-Performance Cathode for the next Generation of Solid-Oxide Fuel Cells. Nature 2004, 431, 170-173.

(37) Chen, C.-H.; Chang, C.-L.; Hwang, B.-H. Electrochemical and Microstructure Characteristics of $\mathrm{Ba}_{0.5} \mathrm{Sr}_{0.5} \mathrm{Co}_{0.8} \mathrm{Fe}_{0.2} \mathrm{O}_{3-\delta}$ (BSCF) Cathodes Prepared by Citrate Precursor Method for SOFCs. Mater. Chem. Phys. 2009, 115, 478-482.

(38) Perry Murray, E. (La,Sr) $\mathrm{MnO}_{3}-(\mathrm{Ce}, \mathrm{Gd}) \mathrm{O}_{2-\mathrm{x}}$ Composite Cathodes for Solid Oxide Fuel Cells. Solid State Ionics 2001, 143, 265-273.

(39) Kim, G.; Wang, S.; Jacobson, A. J.; Reimus, L.; Brodersen, P.; Mims, C. A. Rapid Oxygen Ion Diffusion and Surface Exchange Kinetics in $\mathrm{PrBaCo}_{2} \mathrm{O}_{5+x}$ with a Perovskite Related Structure and Ordered A Cations. J. Mater. Chem. 2007, 17 (24), 2500.

(40) Chen, D.; Ran, R.; Zhang, K.; Wang, J.; Shao, Z. Intermediate-Temperature Electrochemical Performance of a Polycrystalline $\mathrm{PrBaCo}_{2} \mathrm{O}_{5+\delta}$ Cathode on SamariumDoped Ceria Electrolyte. J. Power Sources 2009, 188, 96-105.

(41) Jiang, S. A Comparison of $\mathrm{O}_{2}$ Reduction Reactions on Porous (La,Sr) $\mathrm{MnO}_{3}$ and (La,Sr)(Co,Fe)O3 Electrodes. Solid State Ionics 2002, 146, 1-22.

(42) Esquirol, A.; Brandon, N. P.; Kilner, J. A.; Mogensen, M. Electrochemical Characterization 
of $\mathrm{La}_{0.6} \mathrm{Sr}_{0.4} \mathrm{Co}_{0.2} \mathrm{Fe}_{0.8} \mathrm{O}_{3}$ Cathodes for Intermediate-Temperature SOFCs. J. Electrochem. Soc. 2004, 151, A1847.

(43) Lee, Y. L.; Kleis, J.; Rossmeisl, J.; Morgan, D. Ab Initio Energetics of $\mathrm{LaBO}_{3}(001)(\mathrm{B}=\mathrm{Mn}$, Fe, Co, and Ni) for Solid Oxide Fuel Cell Cathodes. Phys. Rev. B - Condens. Matter Mater. Phys. 2009, 80, 1-20.

(44) Johnsson, M.; Lemmens, P. Crystallography and Chemistry of Perovskites. Handb. Magn. Adv. Magn. Mater. 2007, 4, 1-9.

(45) Kuhar, K.; Pandey, M.; Thygesen, K. S.; Jacobsen, K. W. High-Throughput Computational Assessment of Previously Synthesized Semiconductors for Photovoltaic and Photoelectrochemical Devices. ACS Energy Lett. 2018, 3, 436-446. 


\title{
Supporting Information
}

\section{High-Throughput Computational Screening of Cubic Perovskites for Solid Oxide Fuel Cell Cathodes}

\author{
Ilker Tezsevin $^{a, b, c}$, Mauritius C. M. van de Sanden ${ }^{a, c}$, Süleyman Er ${ }^{a, b, *}$
}

${ }^{a}$ DIFFER - Dutch Institute for Fundamental Energy Research, De Zaale 20, 5612 AJ Eindhoven, The Netherlands

${ }^{\mathrm{b}}$ CCER - Center for Computational Energy Research, De Zaale 20, 5612 AJ Eindhoven, The Netherlands

${ }^{\mathrm{c}}$ Department of Applied Physics, Eindhoven University of Technology, P.O. Box 513, 5600 MB Eindhoven, The Netherlands

* Corresponding Author, e-mail: s.er@differ.nl 


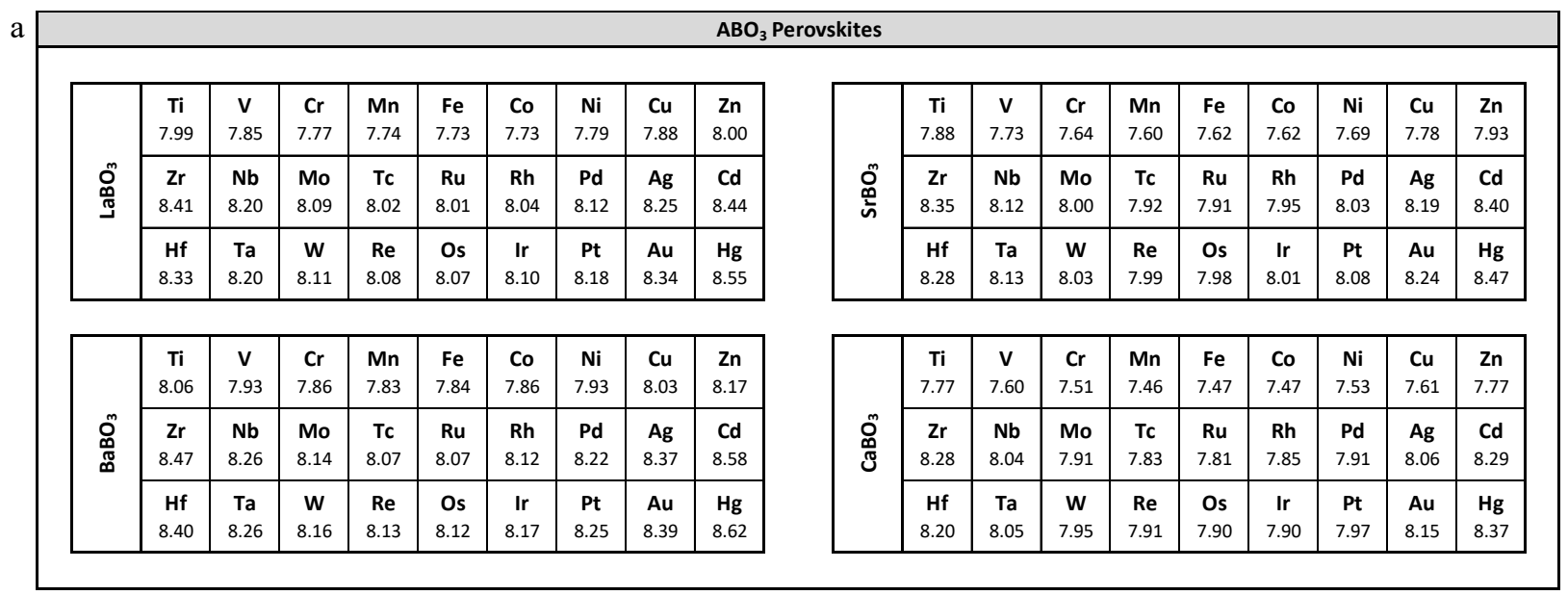

\begin{tabular}{|c|c|c|c|c|c|c|c|c|c|c|c|c|c|c|c|c|c|c|c|}
\hline \multicolumn{20}{|c|}{$\mathrm{A}_{0.5}^{\prime} \mathrm{A}_{0.5}^{\prime \prime} \mathrm{BO}_{3}$ Perovskites } \\
\hline \multirow{4}{*}{ 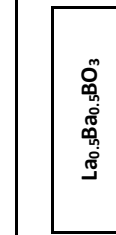 } & & & & & & & & & & \multirow{4}{*}{ 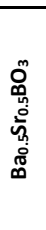 } & \multirow[b]{2}{*}{$\begin{array}{c}\mathrm{Ti} \\
7.97\end{array}$} & \multirow[b]{2}{*}{$\begin{array}{c}\mathbf{V} \\
7.83\end{array}$} & \multirow[b]{2}{*}{$\begin{array}{c}\mathrm{Cr} \\
7.75\end{array}$} & \multirow[b]{2}{*}{$\begin{array}{l}\mathrm{Mn} \\
7.72\end{array}$} & \multirow[b]{2}{*}{$\begin{array}{c}\mathrm{Fe} \\
7.73\end{array}$} & \multirow[b]{2}{*}{$\begin{array}{l}\text { Co } \\
7.74\end{array}$} & \multirow[b]{2}{*}{$\begin{array}{c}\mathbf{N i} \\
7.81\end{array}$} & \multirow[b]{2}{*}{$\begin{array}{c}\mathrm{Cu} \\
7.90\end{array}$} & \multirow[b]{2}{*}{$\begin{array}{c}\mathrm{Zn} \\
8.05\end{array}$} \\
\hline & $\begin{array}{c}\mathrm{Ti} \\
7.99\end{array}$ & $\begin{array}{c}\mathbf{V} \\
7.85\end{array}$ & $\begin{array}{c}\mathrm{Cr} \\
7.77\end{array}$ & $\begin{array}{l}\mathrm{Mn} \\
7.74\end{array}$ & $\begin{array}{c}\mathrm{Fe} \\
7.73\end{array}$ & $\begin{array}{c}\text { Co } \\
7.73\end{array}$ & $\begin{array}{c}\mathbf{N i} \\
7.79\end{array}$ & $\begin{array}{c}\mathrm{Cu} \\
7.88\end{array}$ & $\begin{array}{c}\mathrm{Zn} \\
8.00\end{array}$ & & & & & & & & & & \\
\hline & $\begin{array}{c}\mathrm{Zr} \\
8.41\end{array}$ & $\begin{array}{c}\mathbf{N b} \\
8.20\end{array}$ & $\begin{array}{l}\text { Mo } \\
8.09\end{array}$ & $\begin{array}{c}\text { Tc } \\
8.02\end{array}$ & $\begin{array}{c}\mathbf{R u} \\
8.01\end{array}$ & $\begin{array}{c}\mathbf{R h} \\
8.04\end{array}$ & $\begin{array}{c}\mathbf{P d} \\
8.12\end{array}$ & $\begin{array}{c}\mathbf{A g} \\
8.25\end{array}$ & $\begin{array}{c}\text { Cd } \\
8.44\end{array}$ & & $\begin{array}{c}\mathrm{Zr} \\
8.41\end{array}$ & $\begin{array}{c}\mathbf{N b} \\
8.19\end{array}$ & $\begin{array}{l}\text { Mo } \\
8.07\end{array}$ & $\begin{array}{c}\text { Tc } \\
8.00\end{array}$ & $\begin{array}{c}\mathbf{R u} \\
7.99\end{array}$ & $\begin{array}{c}\mathbf{R h} \\
8.04\end{array}$ & $\begin{array}{c}\mathbf{P d} \\
8.11\end{array}$ & $\begin{array}{c}\mathbf{A g} \\
8.27\end{array}$ & $\begin{array}{c}\mathrm{Cd} \\
8.48\end{array}$ \\
\hline & $\begin{array}{c}\mathbf{H f} \\
8.33\end{array}$ & $\begin{array}{c}\text { Ta } \\
8.20\end{array}$ & $\begin{array}{c}\mathbf{W} \\
8.11\end{array}$ & $\begin{array}{c}\mathbf{R e} \\
8.08\end{array}$ & $\begin{array}{c}\text { Os } \\
8.07\end{array}$ & $\begin{array}{c}\mathbf{I r} \\
8.10\end{array}$ & $\begin{array}{c}\mathbf{P t} \\
8.18\end{array}$ & $\begin{array}{c}\mathrm{Au} \\
8.34\end{array}$ & $\begin{array}{c}\mathrm{Hg} \\
8.55\end{array}$ & & $\begin{array}{c}\mathbf{H f} \\
8.34\end{array}$ & $\begin{array}{c}\text { Ta } \\
8.19\end{array}$ & $\begin{array}{c}\mathbf{W} \\
8.09\end{array}$ & $\begin{array}{c}\mathbf{R e} \\
8.06\end{array}$ & $\begin{array}{c}\text { Os } \\
8.05\end{array}$ & $\begin{array}{c}\text { Ir } \\
8.07\end{array}$ & $\begin{array}{c}\text { Pt } \\
8.15\end{array}$ & $\begin{array}{c}\mathrm{Au} \\
8.31\end{array}$ & $\begin{array}{c}\mathrm{Hg} \\
8.54\end{array}$ \\
\hline \multirow{3}{*}{ 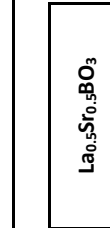 } & $\begin{array}{c}\mathrm{Ti} \\
7.90\end{array}$ & $\begin{array}{c}\mathbf{V} \\
7.75\end{array}$ & $\begin{array}{c}\mathrm{Cr} \\
7.67\end{array}$ & $\begin{array}{l}\mathrm{Mn} \\
7.64\end{array}$ & $\begin{array}{c}\mathrm{Fe} \\
7.63\end{array}$ & $\begin{array}{c}\text { Co } \\
7.63\end{array}$ & $\begin{array}{c}\mathbf{N i} \\
7.68\end{array}$ & $\begin{array}{c}\mathrm{Cu} \\
7.76\end{array}$ & $\begin{array}{c}\text { Zn } \\
7.89\end{array}$ & \multirow{3}{*}{ 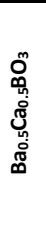 } & $\begin{array}{c}\mathrm{Ti} \\
7.92\end{array}$ & $\begin{array}{c}\mathbf{V} \\
7.77\end{array}$ & $\begin{array}{c}\mathrm{Cr} \\
7.69\end{array}$ & $\begin{array}{l}\mathrm{Mn} \\
7.65\end{array}$ & $\begin{array}{c}\mathrm{Fe} \\
7.66\end{array}$ & $\begin{array}{c}\text { Co } \\
7.66\end{array}$ & $\begin{array}{c}\mathbf{N i} \\
7.72\end{array}$ & $\begin{array}{c}\mathrm{Cu} \\
7.81\end{array}$ & $\begin{array}{c}\mathrm{Zn} \\
7.96\end{array}$ \\
\hline & $\begin{array}{c}\mathrm{Zr} \\
8.34\end{array}$ & $\begin{array}{c}\mathbf{N b} \\
8.13\end{array}$ & $\begin{array}{l}\text { Mo } \\
8.02\end{array}$ & $\begin{array}{c}\text { Tc } \\
7.95\end{array}$ & $\begin{array}{c}\text { Ru } \\
7.94\end{array}$ & $\begin{array}{l}\text { Rh } \\
7.97\end{array}$ & $\begin{array}{c}\mathbf{P d} \\
8.04\end{array}$ & $\begin{array}{c}\mathrm{Ag} \\
8.17\end{array}$ & $\begin{array}{c}\text { Cd } \\
8.33\end{array}$ & & $\begin{array}{c}\mathrm{Zr} \\
8.37\end{array}$ & $\begin{array}{c}\mathbf{N b} \\
8.15\end{array}$ & $\begin{array}{l}\text { Mo } \\
8.03\end{array}$ & $\begin{array}{c}\text { Tc } \\
7.95\end{array}$ & $\begin{array}{c}\text { Ru } \\
7.94\end{array}$ & $\begin{array}{l}\text { Rh } \\
7.97\end{array}$ & $\begin{array}{c}\mathbf{P d} \\
8.05\end{array}$ & $\begin{array}{c}\mathbf{A g} \\
8.20\end{array}$ & $\begin{array}{c}\mathrm{Cd} \\
8.43\end{array}$ \\
\hline & $\begin{array}{c}\mathbf{H f} \\
8.28\end{array}$ & $\begin{array}{c}\text { Ta } \\
8.14\end{array}$ & $\begin{array}{c}\text { W } \\
8.05\end{array}$ & $\begin{array}{c}\mathbf{R e} \\
8.02\end{array}$ & $\begin{array}{c}\text { Os } \\
8.01\end{array}$ & $\begin{array}{c}\text { Ir } \\
8.04\end{array}$ & $\begin{array}{c}\mathbf{P t} \\
8.12\end{array}$ & $\begin{array}{c}\mathrm{Au} \\
8.28\end{array}$ & $\begin{array}{l}\mathrm{Hg} \\
8.49\end{array}$ & & $\begin{array}{c}\mathbf{H f} \\
8.30\end{array}$ & $\begin{array}{c}\text { Ta } \\
8.16\end{array}$ & $\begin{array}{c}\text { W } \\
8.05\end{array}$ & $\begin{array}{c}\mathbf{R e} \\
8.01\end{array}$ & $\begin{array}{c}\text { Os } \\
8.00\end{array}$ & $\begin{array}{c}\text { Ir } \\
8.01\end{array}$ & $\begin{array}{c}\text { Pt } \\
8.09\end{array}$ & $\begin{array}{c}\mathbf{A u} \\
8.25\end{array}$ & $\begin{array}{c}\mathrm{Hg} \\
8.49\end{array}$ \\
\hline \multirow{3}{*}{ 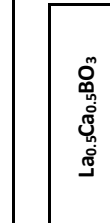 } & $\begin{array}{c}\mathbf{T i} \\
7.85\end{array}$ & $\begin{array}{c}\mathbf{V} \\
7.70\end{array}$ & $\begin{array}{c}\mathrm{Cr} \\
7.62\end{array}$ & $\begin{array}{l}\mathrm{Mn} \\
7.57\end{array}$ & $\begin{array}{c}\mathrm{Fe} \\
7.57\end{array}$ & $\begin{array}{c}\text { Co } \\
7.57\end{array}$ & $\begin{array}{c}\mathbf{N i} \\
7.61\end{array}$ & $\begin{array}{c}\mathrm{Cu} \\
7.69\end{array}$ & $\begin{array}{c}\mathrm{Zn} \\
7.83\end{array}$ & \multirow{3}{*}{ 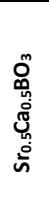 } & $\begin{array}{c}\mathrm{Ti} \\
7.83\end{array}$ & $\begin{array}{c}\mathbf{V} \\
7.67\end{array}$ & $\begin{array}{c}\mathrm{Cr} \\
7.58\end{array}$ & $\begin{array}{l}\mathrm{Mn} \\
7.54\end{array}$ & $\begin{array}{c}\mathrm{Fe} \\
7.55\end{array}$ & $\begin{array}{l}\text { Co } \\
7.55\end{array}$ & $\begin{array}{c}\mathbf{N i} \\
7.60\end{array}$ & $\begin{array}{c}\mathrm{Cu} \\
7.69\end{array}$ & $\begin{array}{c}\mathrm{Zn} \\
7.85\end{array}$ \\
\hline & $\begin{array}{c}\mathrm{Zr} \\
8.32\end{array}$ & $\begin{array}{c}\mathbf{N b} \\
8.09\end{array}$ & $\begin{array}{l}\text { Mo } \\
7.98\end{array}$ & $\begin{array}{c}\text { Tc } \\
7.91\end{array}$ & $\begin{array}{c}\mathbf{R u} \\
7.90\end{array}$ & $\begin{array}{l}\text { Rh } \\
7.92\end{array}$ & $\begin{array}{c}\text { Pd } \\
8.00\end{array}$ & $\begin{array}{c}\mathbf{A g} \\
8.12\end{array}$ & $\begin{array}{c}\text { Cd } \\
8.33\end{array}$ & & $\begin{array}{c}\mathrm{Zr} \\
8.31\end{array}$ & $\begin{array}{c}\mathbf{N b} \\
8.08\end{array}$ & $\begin{array}{l}\text { Mo } \\
7.96\end{array}$ & $\begin{array}{c}\text { Tc } \\
7.87\end{array}$ & $\begin{array}{c}\mathbf{R u} \\
7.86\end{array}$ & $\begin{array}{c}\text { Rh } \\
7.90\end{array}$ & $\begin{array}{l}\mathbf{P d} \\
7.97\end{array}$ & $\begin{array}{c}\mathbf{A g} \\
8.12\end{array}$ & $\begin{array}{c}\mathrm{Cd} \\
8.35\end{array}$ \\
\hline & $\begin{array}{c}\mathbf{H f} \\
8.24\end{array}$ & $\begin{array}{c}\text { Ta } \\
8.10\end{array}$ & $\begin{array}{c}\mathbf{W} \\
8.00\end{array}$ & $\begin{array}{c}\mathbf{R e} \\
7.98\end{array}$ & $\begin{array}{c}\text { Os } \\
7.98\end{array}$ & $\begin{array}{c}\text { Ir } \\
8.00\end{array}$ & $\begin{array}{c}\mathbf{P t} \\
8.09\end{array}$ & $\begin{array}{c}\mathbf{A u} \\
8.24\end{array}$ & $\begin{array}{c}\mathrm{Hg} \\
8.49\end{array}$ & & $\begin{array}{c}\text { Hf } \\
8.24\end{array}$ & $\begin{array}{c}\text { Ta } \\
8.09\end{array}$ & $\begin{array}{c}\mathbf{W} \\
7.99\end{array}$ & $\begin{array}{c}\mathbf{R e} \\
7.95\end{array}$ & $\begin{array}{c}\text { Os } \\
7.94\end{array}$ & $\begin{array}{c}\text { Ir } \\
7.95\end{array}$ & $\begin{array}{c}\mathbf{P t} \\
8.02\end{array}$ & $\begin{array}{c}\mathrm{Au} \\
8.18\end{array}$ & $\begin{array}{c}\mathrm{Hg} \\
8.42\end{array}$ \\
\hline
\end{tabular}

Figure S1. DFT optimized lattice parameters of a) $\mathrm{ABO}_{3}$ and b) $\mathrm{A}_{0.5}^{\mathrm{I}} \mathrm{A}_{0.5}^{\mathrm{II}} \mathrm{BO}_{3}$ cubic $(P m 3 m)$ perovskite supercells. All units are given in $\AA$. 

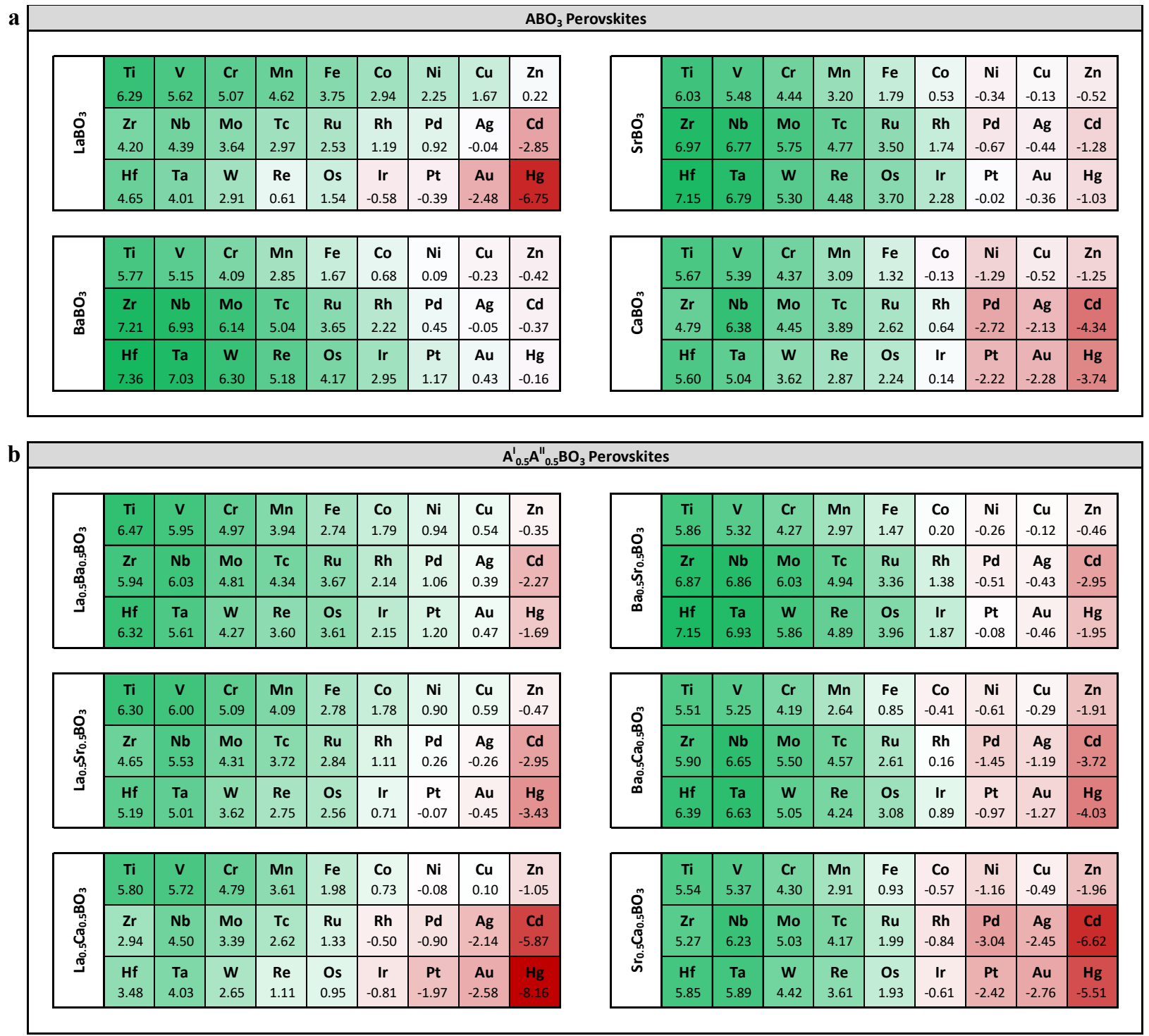

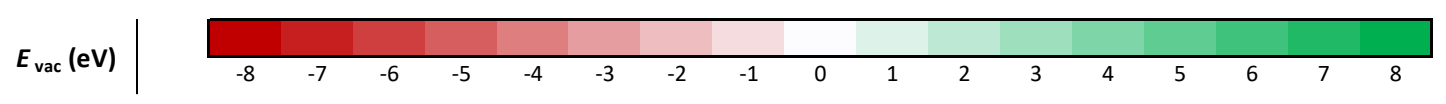

Figure S2. DFT calculated oxygen vacancy formation energy $\left(E_{\mathrm{vac}}\right)$ of a) $\mathrm{ABO}_{3}$ and b) $\mathrm{A}_{0.5}^{\mathrm{I}} \mathrm{A}^{\mathrm{II}}{ }_{0.5} \mathrm{BO}_{3}$ perovskites. The likely stable perovskites are shown with green-shaded boxes and the likely unstable perovskites are shown with red-shaded boxes. All units are given in eV. 


\begin{tabular}{|c|c|c|c|c|c|c|c|c|c|}
\hline \multirow{4}{*}{ 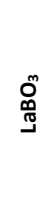 } & $\begin{array}{c}\mathbf{T i} \\
91.05\end{array}$ & $\begin{array}{c}\mathbf{V} \\
31.94\end{array}$ & $\begin{array}{c}\mathrm{Cr} \\
13.50\end{array}$ & $\begin{array}{l}\mathrm{Mn} \\
6.68\end{array}$ & $\begin{array}{c}\mathrm{Fe} \\
1.71\end{array}$ & $\begin{array}{c}\text { Co } \\
0.48\end{array}$ & $\begin{array}{c}\mathbf{N i} \\
0.16\end{array}$ & $\begin{array}{c}\mathrm{Cu} \\
0.07\end{array}$ & $\begin{array}{c}\text { Zn } \\
0.01\end{array}$ \\
\hline & $\mathrm{Zr}$ & $\mathrm{Nb}$ & Mo & Tc & $\mathbf{R u}$ & $\mathbf{R h}$ & $\mathbf{P d}$ & $\mathbf{A g}$ & $C d$ \\
\hline & 3.46 & 4.62 & 1.43 & 0.50 & 0.25 & 0.03 & 0.02 & & \\
\hline & $\begin{array}{c}\mathbf{H f} \\
6.93\end{array}$ & $\begin{array}{c}\text { Ta } \\
2.56\end{array}$ & $\begin{array}{c}\mathbf{W} \\
0.46\end{array}$ & $\begin{array}{c}\mathbf{R e} \\
0.01\end{array}$ & $\begin{array}{c}\text { Os } \\
0.05\end{array}$ & Ir & Pt & $\mathrm{Au}$ & $\mathrm{Hg}$ \\
\hline
\end{tabular}

\begin{tabular}{|c|c|c|c|c|c|c|c|c|c|}
\hline \multirow{3}{*}{$\begin{array}{l}\text { O̊ } \\
\text { ங் }\end{array}$} & $\begin{array}{c}\mathrm{Ti} \\
60.06\end{array}$ & $\begin{array}{c}\mathbf{V} \\
25.31\end{array}$ & $\begin{array}{c}\mathrm{Cr} \\
5.04\end{array}$ & $\begin{array}{l}\text { Mn } \\
0.72\end{array}$ & $\begin{array}{c}\mathrm{Fe} \\
0.08\end{array}$ & $\begin{array}{c}\text { Co } \\
0.01\end{array}$ & $\mathrm{Ni}$ & $\mathrm{Cu}$ & $\mathrm{Zn}$ \\
\hline & $\begin{array}{c}\mathbf{Z r} \\
262.23\end{array}$ & $\begin{array}{c}\mathbf{N b} \\
191.89\end{array}$ & $\begin{array}{c}\text { Mo } \\
38.79\end{array}$ & $\begin{array}{c}\text { Tc } \\
8.34\end{array}$ & $\begin{array}{c}\mathbf{R u} \\
1.14\end{array}$ & $\begin{array}{c}\mathbf{R h} \\
0.07\end{array}$ & $\mathbf{P d}$ & $\mathrm{Ag}$ & $\mathrm{Cd}$ \\
\hline & $\begin{array}{c}\text { Hf } \\
346.81\end{array}$ & $\begin{array}{c}\text { Ta } \\
199.45\end{array}$ & $\begin{array}{c}\text { W } \\
19.14\end{array}$ & $\begin{array}{c}\mathbf{R e} \\
5.32\end{array}$ & $\begin{array}{c}\text { Os } \\
1.56\end{array}$ & $\begin{array}{c}\text { Ir } \\
0.17\end{array}$ & $\mathrm{Pt}$ & $\mathrm{Au}$ & $\mathrm{Hg}$ \\
\hline
\end{tabular}

\begin{tabular}{|c|c|c|c|c|c|c|c|c|c|}
\hline \multirow{3}{*}{ 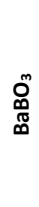 } & $\begin{array}{c}\mathbf{T i} \\
39.96\end{array}$ & $\begin{array}{c}\mathbf{V} \\
15.32\end{array}$ & $\begin{array}{c}\mathrm{Cr} \\
2.91\end{array}$ & $\begin{array}{l}\text { Mn } \\
0.41\end{array}$ & $\begin{array}{c}\mathrm{Fe} \\
0.07\end{array}$ & $\begin{array}{c}\text { Co } \\
0.01\end{array}$ & $\begin{array}{c}\mathbf{N i} \\
0.01\end{array}$ & $\mathrm{Cu}$ & $\mathrm{Zn}$ \\
\hline & $\begin{array}{c}\mathbf{Z r} \\
379.67\end{array}$ & $\begin{array}{c}\mathbf{N b} \\
245.13\end{array}$ & $\begin{array}{c}\text { Mo } \\
71.16\end{array}$ & $\begin{array}{c}\text { Tc } \\
12.72\end{array}$ & $\begin{array}{c}\mathbf{R u} \\
1.45\end{array}$ & $\begin{array}{c}\text { Rh } \\
0.15\end{array}$ & $\begin{array}{c}\text { Pd } \\
0.01\end{array}$ & $\mathrm{Ag}$ & $\mathrm{Cd}$ \\
\hline & $\begin{array}{c}\text { Hf } \\
480.77\end{array}$ & $\begin{array}{c}\text { Ta } \\
287.56\end{array}$ & $\begin{array}{c}\mathbf{W} \\
92.13\end{array}$ & $\begin{array}{c}\mathbf{R e} \\
16.05\end{array}$ & $\begin{array}{c}\text { Os } \\
3.27\end{array}$ & $\begin{array}{c}\text { Ir } \\
0.48\end{array}$ & $\begin{array}{c}\text { Pt } \\
0.03\end{array}$ & $\begin{array}{l}\text { Au } \\
0.01\end{array}$ & $\mathrm{Hg}$ \\
\hline
\end{tabular}

\begin{tabular}{|c|c|c|c|c|c|c|c|c|c|}
\hline \multirow{3}{*}{$\begin{array}{l}\text { ర్ల } \\
\text { ర్ల }\end{array}$} & $\begin{array}{c}\mathbf{T i} \\
34.31\end{array}$ & $\begin{array}{c}\mathbf{V} \\
22.19\end{array}$ & $\begin{array}{c}\mathrm{Cr} \\
4.51\end{array}$ & $\begin{array}{l}\text { Mn } \\
0.60\end{array}$ & $\begin{array}{c}\mathrm{Fe} \\
0.04\end{array}$ & Co & $\mathbf{N i}$ & $\mathrm{Cu}$ & $\mathrm{Zn}$ \\
\hline & $\begin{array}{c}\mathrm{Zr} \\
8.70\end{array}$ & $\begin{array}{c}\mathbf{N b} \\
104.05\end{array}$ & $\begin{array}{l}\text { Mo } \\
5.07\end{array}$ & $\begin{array}{c}\text { Tc } \\
2.11\end{array}$ & $\begin{array}{c}\mathbf{R u} \\
0.29\end{array}$ & $\begin{array}{c}\mathbf{R h} \\
0.01\end{array}$ & $\mathbf{P d}$ & $\mathrm{Ag}$ & $C d$ \\
\hline & $\begin{array}{c}\text { Hf } \\
30.77\end{array}$ & $\begin{array}{c}\text { Ta } \\
12.73\end{array}$ & $\begin{array}{c}\mathbf{W} \\
1.38\end{array}$ & $\begin{array}{c}\mathbf{R e} \\
0.43\end{array}$ & $\begin{array}{c}\text { Os } \\
0.16\end{array}$ & $\begin{array}{c}\text { Ir } \\
0.01\end{array}$ & $\mathrm{Pt}$ & $\mathrm{Au}$ & $\mathrm{Hg}$ \\
\hline
\end{tabular}

b

\begin{tabular}{|c|c|c|c|c|c|c|c|c|c|}
\hline & & & & & & & & & ${ }_{5.5} \mathrm{~A}^{\prime \prime}$ \\
\hline \multirow{3}{*}{ 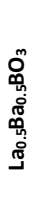 } & $\begin{array}{c}\mathbf{T i} \\
119.72\end{array}$ & $\begin{array}{c}\mathbf{V} \\
52.94\end{array}$ & $\begin{array}{c}\mathrm{Cr} \\
11.52\end{array}$ & $\begin{array}{l}\mathrm{Mn} \\
2.30\end{array}$ & $\begin{array}{c}\text { Fe } \\
0.35\end{array}$ & $\begin{array}{c}\text { Co } \\
0.08\end{array}$ & $\begin{array}{c}\mathbf{N i} \\
0.02\end{array}$ & $\begin{array}{c}\mathrm{Cu} \\
0.01\end{array}$ & $\mathrm{Zn}$ \\
\hline & $\begin{array}{c}\mathrm{Zr} \\
52.22\end{array}$ & $\begin{array}{c}\mathbf{N b} \\
60.04\end{array}$ & $\begin{array}{l}\text { Mo } \\
8.94\end{array}$ & $\begin{array}{c}\text { Tc } \\
4.30\end{array}$ & $\begin{array}{c}\mathbf{R u} \\
1.50\end{array}$ & $\begin{array}{c}\text { Rh } \\
0.14\end{array}$ & $\begin{array}{c}\mathbf{P d} \\
0.03\end{array}$ & $\begin{array}{c}\mathbf{A g} \\
0.01\end{array}$ & $\mathrm{Cd}$ \\
\hline & $\begin{array}{c}\text { Hf } \\
94.33\end{array}$ & $\begin{array}{c}\text { Ta } \\
31.19\end{array}$ & $\begin{array}{c}\mathbf{W} \\
3.83\end{array}$ & $\begin{array}{c}\mathbf{R e} \\
1.34\end{array}$ & $\begin{array}{c}\text { Os } \\
1.37\end{array}$ & $\begin{array}{c}\text { Ir } \\
0.14\end{array}$ & $\begin{array}{c}\text { Pt } \\
0.03\end{array}$ & $\begin{array}{c}\mathrm{Au} \\
0.01\end{array}$ & $\mathrm{Hg}$ \\
\hline
\end{tabular}

\begin{tabular}{|c|c|c|c|c|c|c|c|c|c|}
\hline \multirow{3}{*}{ 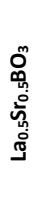 } & $\begin{array}{c}\mathbf{T i} \\
91.53\end{array}$ & $\underset{57.87}{\mathbf{V}}$ & $\begin{array}{c}\mathrm{Cr} \\
13.84\end{array}$ & $\begin{array}{l}\mathrm{Mn} \\
2.90\end{array}$ & $\begin{array}{c}\mathrm{Fe} \\
0.37\end{array}$ & $\begin{array}{c}\text { Co } \\
0.08\end{array}$ & $\begin{array}{c}\mathbf{N i} \\
0.02\end{array}$ & $\begin{array}{c}\mathrm{Cu} \\
0.01\end{array}$ & $\mathrm{Zn}$ \\
\hline & $\begin{array}{c}\mathrm{Zr} \\
6.90\end{array}$ & $\begin{array}{c}\mathbf{N b} \\
27.49\end{array}$ & $\begin{array}{l}\text { Mo } \\
4.07\end{array}$ & $\begin{array}{c}\text { Tc } \\
1.62\end{array}$ & $\begin{array}{c}\mathbf{R u} \\
0.41\end{array}$ & $\begin{array}{c}\mathbf{R h} \\
0.03\end{array}$ & $\begin{array}{c}\mathbf{P d} \\
0.01\end{array}$ & $\mathrm{Ag}$ & $C d$ \\
\hline & $\begin{array}{c}\text { Hf } \\
16.09\end{array}$ & $\begin{array}{c}\text { Ta } \\
12.22\end{array}$ & $\begin{array}{c}\mathbf{W} \\
1.39\end{array}$ & $\begin{array}{c}\mathbf{R e} \\
0.35\end{array}$ & $\begin{array}{c}\text { Os } \\
0.26\end{array}$ & $\begin{array}{c}\text { Ir } \\
0.01\end{array}$ & Pt & $\mathrm{Au}$ & $\mathrm{Hg}$ \\
\hline
\end{tabular}

\begin{tabular}{|c|c|c|c|c|c|c|c|c|c|}
\hline \multirow{3}{*}{ 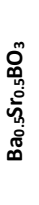 } & $\begin{array}{c}\mathrm{Ti} \\
46.13\end{array}$ & $\begin{array}{c}\mathbf{V} \\
19.89\end{array}$ & $\begin{array}{c}\mathrm{Cr} \\
3.83\end{array}$ & $\begin{array}{l}\text { Mn } \\
0.50\end{array}$ & $\begin{array}{c}\mathrm{Fe} \\
0.05\end{array}$ & $\begin{array}{c}\text { Co } \\
0.01\end{array}$ & $\mathrm{Ni}$ & $\mathrm{Cu}$ & $\mathrm{Zn}$ \\
\hline & $\begin{array}{c}\mathbf{Z r} \\
223.40\end{array}$ & $\begin{array}{c}\mathbf{N b} \\
221.99\end{array}$ & $\begin{array}{c}\text { Mo } \\
60.78\end{array}$ & $\begin{array}{c}\text { Tc } \\
10.91\end{array}$ & $\begin{array}{c}\mathbf{R u} \\
0.92\end{array}$ & $\begin{array}{c}\mathbf{R h} \\
0.04\end{array}$ & Pd & $\mathrm{Ag}$ & $\mathrm{Cd}$ \\
\hline & $\begin{array}{c}\text { Hf } \\
350.16\end{array}$ & $\begin{array}{c}\text { Ta } \\
245.89\end{array}$ & $\begin{array}{c}\mathbf{W} \\
46.45\end{array}$ & $\begin{array}{c}\mathbf{R e} \\
10.04\end{array}$ & $\begin{array}{c}\text { Os } \\
2.37\end{array}$ & $\begin{array}{c}\text { Ir } \\
0.09\end{array}$ & Pt & $\mathrm{Au}$ & $\mathrm{Hg}$ \\
\hline
\end{tabular}

\begin{tabular}{|c|c|c|c|c|c|c|c|c|c|}
\hline \multirow{3}{*}{ 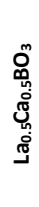 } & $\begin{array}{c}\mathbf{T i} \\
41.90\end{array}$ & $\begin{array}{c}\mathbf{V} \\
37.04\end{array}$ & $\begin{array}{c}\mathrm{Cr} \\
8.67\end{array}$ & $\begin{array}{l}\text { Mn } \\
1.36\end{array}$ & $\begin{array}{c}\mathrm{Fe} \\
0.11\end{array}$ & $\begin{array}{c}\text { Co } \\
0.02\end{array}$ & $\mathrm{Ni}$ & $\begin{array}{c}\mathrm{Cu} \\
0.01\end{array}$ & $\mathrm{Zn}$ \\
\hline & $\begin{array}{c}\mathrm{Zr} \\
0.47\end{array}$ & $\begin{array}{c}\mathbf{N b} \\
5.49\end{array}$ & $\begin{array}{l}\text { Mo } \\
0.97\end{array}$ & $\begin{array}{c}\text { Tc } \\
0.29\end{array}$ & $\begin{array}{c}\mathbf{R u} \\
0.04\end{array}$ & $\mathbf{R h}$ & $\mathbf{P d}$ & $\mathrm{Ag}$ & $\mathrm{Cd}$ \\
\hline & $\begin{array}{c}\mathbf{H f} \\
1.11\end{array}$ & $\begin{array}{c}\mathrm{Ta} \\
2.64\end{array}$ & $\begin{array}{c}\mathbf{W} \\
0.31\end{array}$ & $\begin{array}{c}\mathbf{R e} \\
0.03\end{array}$ & $\begin{array}{c}\text { Os } \\
0.02\end{array}$ & Ir & Pt & $\mathrm{Au}$ & $\mathrm{Hg}$ \\
\hline
\end{tabular}

\begin{tabular}{|c|c|c|c|c|c|c|c|c|c|}
\hline \multirow{3}{*}{ 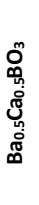 } & $\begin{array}{c}\mathrm{Ti} \\
26.84\end{array}$ & $\begin{array}{c}\mathbf{V} \\
17.90\end{array}$ & $\begin{array}{c}\mathrm{Cr} \\
3.37\end{array}$ & $\begin{array}{l}\text { Mn } \\
0.30\end{array}$ & $\begin{array}{c}\mathrm{Fe} \\
0.02\end{array}$ & Co & $\mathrm{Ni}$ & $\mathrm{Cu}$ & Zn \\
\hline & $\begin{array}{c}\mathbf{Z r} \\
49.19\end{array}$ & $\begin{array}{c}\mathbf{N b} \\
159.27\end{array}$ & $\begin{array}{c}\text { Mo } \\
26.24\end{array}$ & $\begin{array}{c}\text { Tc } \\
6.16\end{array}$ & $\begin{array}{c}\mathbf{R u} \\
0.28\end{array}$ & $\begin{array}{c}\mathbf{R h} \\
0.01\end{array}$ & $\mathbf{P d}$ & $\mathrm{Ag}$ & $\mathrm{Cd}$ \\
\hline & $\begin{array}{c}\text { Hf } \\
106.23\end{array}$ & $\begin{array}{c}\text { Ta } \\
155.42\end{array}$ & $\begin{array}{c}\mathbf{W} \\
13.09\end{array}$ & $\begin{array}{c}\mathbf{R e} \\
3.64\end{array}$ & $\begin{array}{c}\text { Os } \\
0.59\end{array}$ & $\begin{array}{c}\text { Ir } \\
0.02\end{array}$ & Pt & $\mathrm{Au}$ & $\mathrm{Hg}$ \\
\hline
\end{tabular}

\begin{tabular}{|c|c|c|c|c|c|c|c|c|c|}
\hline \multirow{3}{*}{ 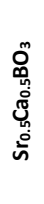 } & $\begin{array}{c}\mathrm{Ti} \\
27.98\end{array}$ & $\begin{array}{c}\mathbf{V} \\
21.50\end{array}$ & $\begin{array}{c}\mathrm{Cr} \\
4.03\end{array}$ & $\begin{array}{l}\text { Mn } \\
0.45\end{array}$ & $\begin{array}{c}\mathrm{Fe} \\
0.02\end{array}$ & Co & $\mathrm{Ni}$ & $\mathrm{Cu}$ & $\mathrm{Zn}$ \\
\hline & $\begin{array}{c}\mathbf{Z r} \\
18.22\end{array}$ & $\begin{array}{c}\mathbf{N b} \\
82.65\end{array}$ & $\begin{array}{c}\text { Mo } \\
12.51\end{array}$ & $\begin{array}{c}\text { Tc } \\
3.27\end{array}$ & $\begin{array}{c}\mathbf{R u} \\
0.11\end{array}$ & $\mathbf{R h}$ & Pd & $\mathrm{Ag}$ & $\mathrm{Cd}$ \\
\hline & $\begin{array}{c}\text { Hf } \\
45.59\end{array}$ & $\begin{array}{c}\text { Ta } \\
48.51\end{array}$ & $\begin{array}{c}\text { W } \\
4.88\end{array}$ & $\begin{array}{c}\mathbf{R e} \\
1.36\end{array}$ & $\begin{array}{c}\text { Os } \\
0.10\end{array}$ & Ir & Pt & $\mathrm{Au}$ & $\mathrm{Hg}$ \\
\hline
\end{tabular}

Figure S3. Estimated $A S R\left(\Omega \mathrm{cm}^{2}\right)$ data of a) $\mathrm{ABO}_{3}$ and b) $\mathrm{A}_{0.5}^{\mathrm{I}} \mathrm{A}^{\mathrm{II}}{ }_{0.5} \mathrm{BO}_{3}$ perovskites. The perovskites with promising $A S R$ data are shown with blue-shaded boxes. $A S R$ data for the likely unstable perovskites $\left(E_{\mathrm{vac}}<0 \mathrm{eV}\right)$ is not shown. 


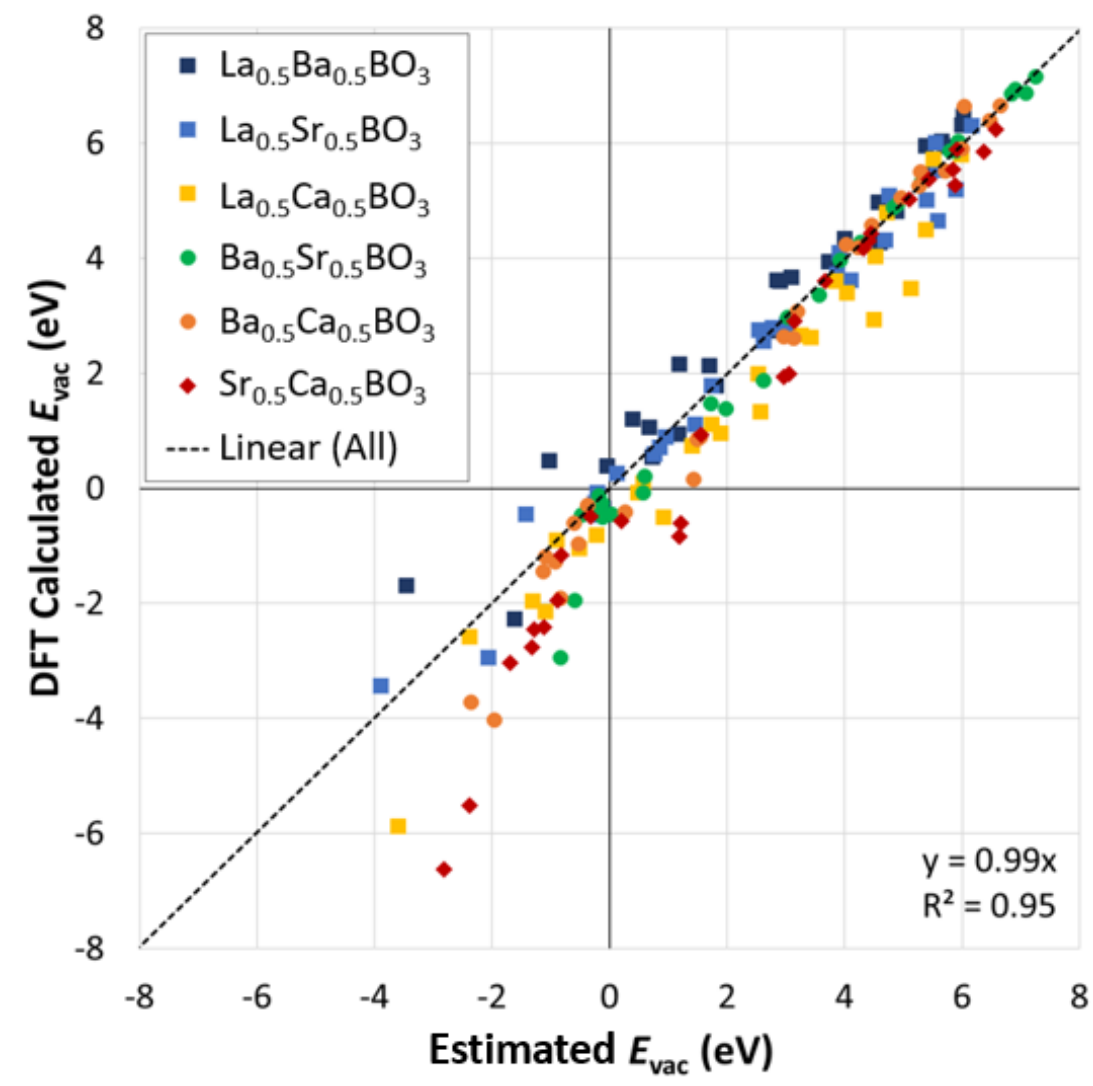

Figure S4. Comparison of the calculated and the estimated oxygen vacancy formation energy of at the whole set of $\mathrm{A}_{0.5}^{\mathrm{I}} \mathrm{A}^{\mathrm{II}_{0.5}} \mathrm{BO}_{3}$ perovskites that are covered in this study. 

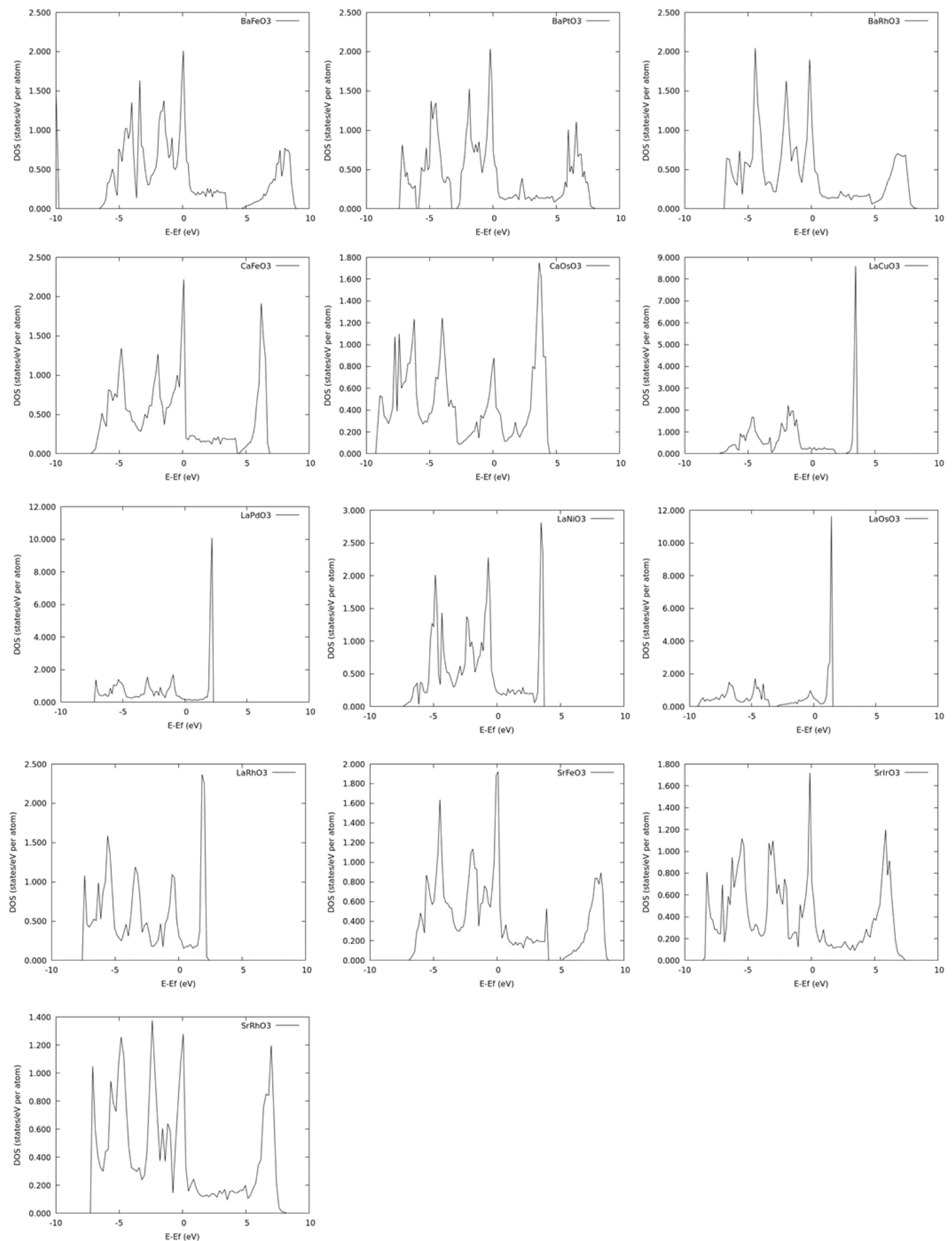

Figure S5. Density of states (DOS) plots of the best candidate $\mathrm{ABO}_{3}$ perovskites for SOFC cathodes (see also Figure S7). The origin of the energy scale was set at the Fermi level. 

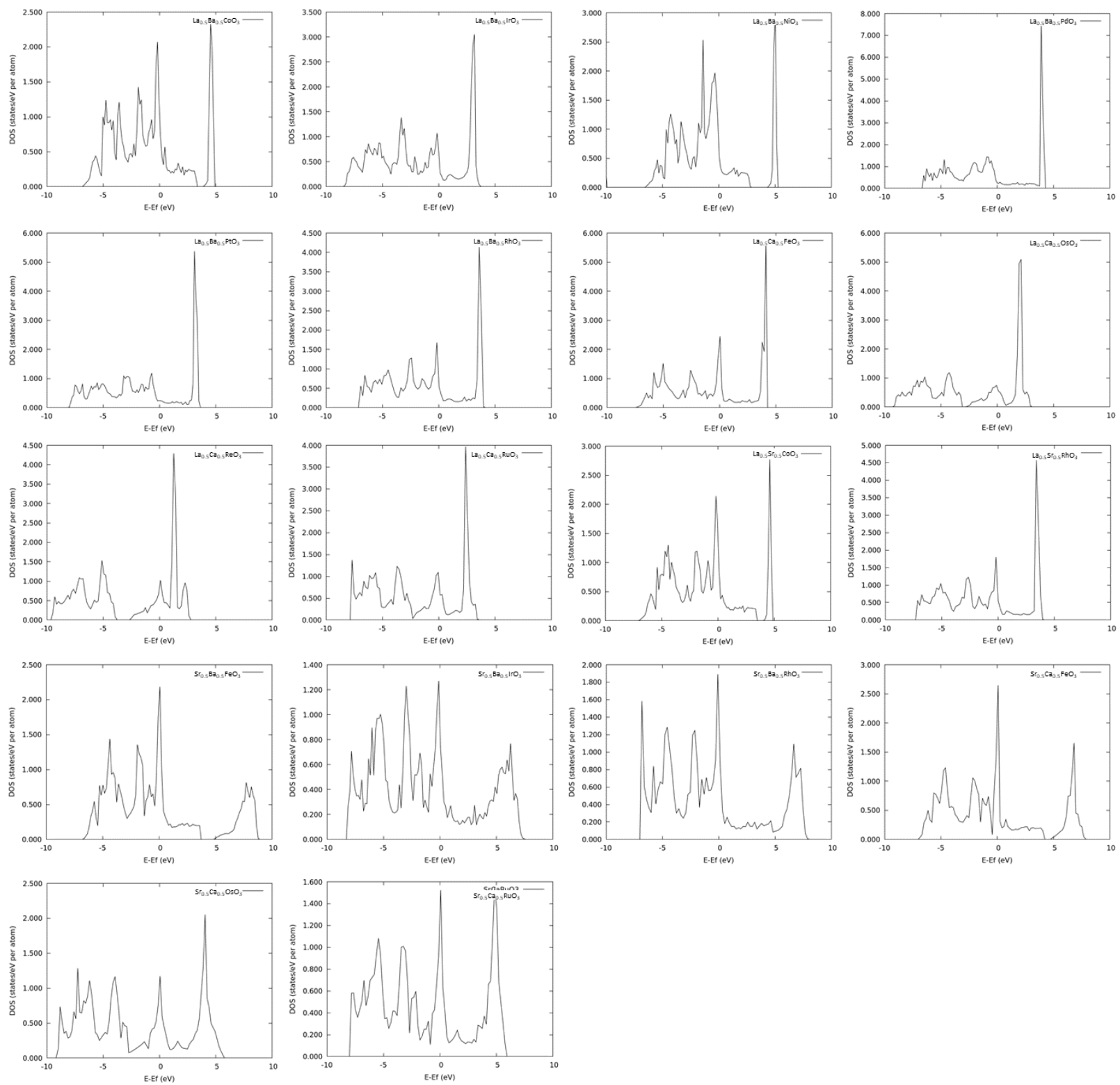

Figure S6. DOS plots of the best candidate $\mathrm{A}_{0.5}^{\mathrm{I}} \mathrm{A}_{0.5}^{\mathrm{II}} \mathrm{BO}_{3}$ perovskites for $\mathrm{SOFC}$ cathodes (see also Figure S8). The origin of the energy scale was set at the Fermi level. 

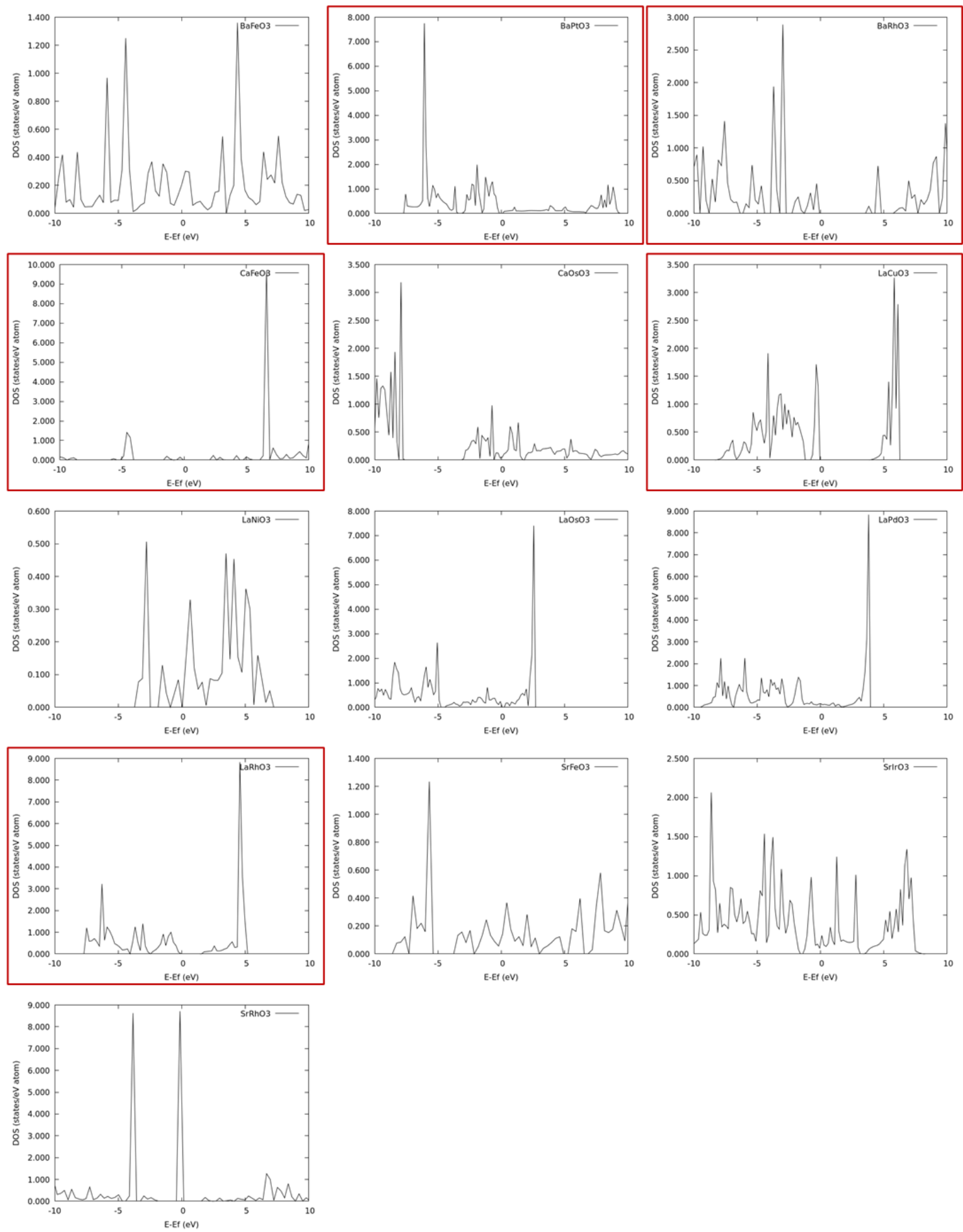

Figure S7. HSE06 calculated DOS plots of the best candidate $\mathrm{ABO}_{3}$ perovskites.

Note that the DOS plots that have been obtained by using the HSE06 functional show band gaps for $\mathrm{BaPtO}_{3}, \mathrm{BaRhO}_{3}, \mathrm{CaFeO}_{3}, \mathrm{LaCuO}_{3}, \mathrm{LaRhO}_{3}$. Although the finest $k$-point mesh that could be employed in these calculations was only $2 \times 2 \times 2$, the electronic conductivity of these compounds is expected to be less promising than the remaining compounds shown in this figure. 

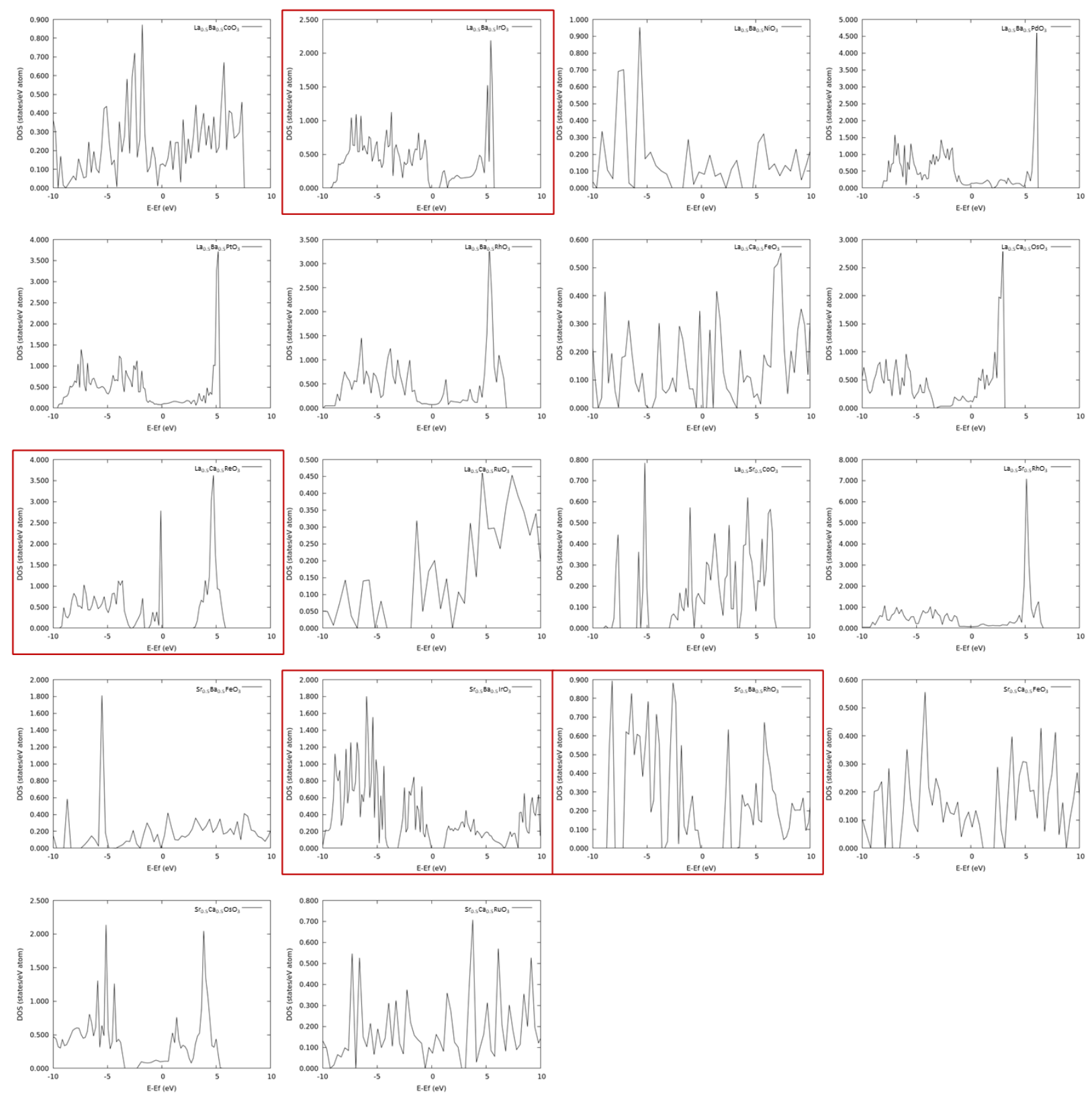

Figure S8. HSE06 calculated DOS plots of the best candidate $\mathrm{A}_{0.5}^{\mathrm{I}} \mathrm{A}^{\mathrm{II}}{ }_{0.5} \mathrm{BO}_{3}$ perovskites.

Note that the DOS plots that have been obtained by using the HSE06 functional show band gaps for $\mathrm{La}_{0.5} \mathrm{Ba}_{0.5} \mathrm{IrO}_{3}, \mathrm{La}_{0.5} \mathrm{Ca}_{0.5} \mathrm{ReO}_{3}, \mathrm{Sr}_{0.5} \mathrm{Ba}_{0.5} \mathrm{IrO}_{3}, \mathrm{Sr}_{0.5} \mathrm{Ba}_{0.5} \mathrm{RhO}_{3}$. Although the finest $k$-point mesh that could be employed in these calculations was only $2 \times 2 \times 2$, the electronic conductivity of these compounds is expected to be less promising than the remaining compounds shown in this figure. 


\section{COMPUTATIONAL METHODOLOGY}

We used Vienna ab-initio Simulation Package (VASP) to perform all DFT calculations in the current work. ${ }^{1-3}$ The projector augmented wave (PAW) method is employed to describe electronion interactions. A kinetic energy cutoff of $500 \mathrm{eV}$ is used for the planewave basis for all calculations. ${ }^{4,5}$ We used the Perdew-Burke-Ernzerhof (PBE) exchange-correlation functional of the generalized gradient approximation (GGA). ${ }^{6}$ The convergence criteria for structural optimizations were that the total forces acting on each atom must be smaller than $0.015 \mathrm{eV} / \AA$. The Brillouin zone is integrated using an automatically generated $4 \times 4 \times 4$ Monkhorst-Pack $k$-point mesh for all optimization calculations and using an automatically generated $12 \times 12 \times 12$ Monkhorst-Pack $k$-point mesh for density of state calculations. ${ }^{7}$ To represent $\mathrm{ABO}_{3}$ and $\mathrm{A}^{\mathrm{I}}{ }_{0.5} \mathrm{~A}^{\mathrm{II}}{ }_{0.5} \mathrm{BO}_{3}$ perovskites, 40 atom $\mathrm{A}_{8} \mathrm{~B}_{8} \mathrm{O}_{24}$, and $\mathrm{A}_{4}{ }_{4} \mathrm{~A}^{\mathrm{II}}{ }_{4} \mathrm{~B}_{8} \mathrm{O}_{24}$ supercells with $P m 3 m$ space group are used. ${ }^{8} \mathrm{La}, \mathrm{Ba}, \mathrm{Sr}$, and $\mathrm{Ca}$ are used as A-type cations in the computations. B-type cations are successively used among 27 different transition metals, between the $4^{\text {th }}$ and $12^{\text {th }}$ groups of $4^{\text {th }}, 5^{\text {th }}$, and $6^{\text {th }}$ rows of the periodic table. Accordingly, a virtual chemical library that contains $108 \mathrm{ABO}_{3}$ and $162 \mathrm{~A}_{0.5}^{\mathrm{I}} \mathrm{A}_{0.5}^{\mathrm{II}} \mathrm{BO}_{3}$ perovskites is generated. Out of the three possible bulk configurations of $\mathrm{A}_{0.5}^{\mathrm{I}} \mathrm{A}^{\mathrm{II}}{ }_{0.5} \mathrm{BO}_{3}$ perovskites, only the layered configurations have been considered in relation to the earlier literature results of Maiti et al. ${ }^{9,10}$ Optimization of all structures are performed via three sets of consecutive volume and ionic relaxation calculations, thus in total six steps. Total energies of the oxygen deficient supercells, $\mathrm{A}_{8} \mathrm{~B}_{8} \mathrm{O}_{23}$ and $\mathrm{A}_{4} \mathrm{~A}^{\mathrm{II}}{ }_{4} \mathrm{~B}_{8} \mathrm{O}_{23}$, are computed using a full ionic relaxation scheme and the optimized lattice constants of the supercells with no oxygen vacancy. The calculation for oxygen molecule is performed using a cubic box with $15 \AA$ edge and allowing for spin relaxation. The systematic shift in the oxygen binding energies calculated using PBE has been addressed by using a factor of $1.36 \mathrm{eV}$ per oxygen molecule. ${ }^{10,11}$ For the calculation of $E_{\mathrm{vac}}$, the following equation is applied

$$
E_{\mathrm{vac}}=\left(E_{\mathrm{A}_{8} \mathrm{~B}_{8} \mathrm{O}_{23}}+1 / 2 E_{\mathrm{O}_{2}}\right)-E_{\mathrm{A}_{8} \mathrm{~B}_{8} \mathrm{O}_{24}} \quad \text { Eq. S1 }
$$

which produces the data in eV/supercell. To match the experimentally studied compositions, $\mathrm{Pr}_{4} \mathrm{Ba}_{4} \mathrm{Co}_{8} \mathrm{O}_{24}, \mathrm{La}_{6} \mathrm{Sr}_{2} \mathrm{Mn}_{8} \mathrm{O}_{24}, \mathrm{Ba}_{4} \mathrm{Sr}_{4} \mathrm{Co}_{6} \mathrm{FeO}_{24}$, and $\mathrm{La}_{5} \mathrm{Sr}_{3} \mathrm{Co}_{2} \mathrm{Fe}_{6} \mathrm{O}_{24}$ supercells are used in calculations, which respectively correspond to $\operatorname{Pr}_{0.5} \mathrm{Ba}_{0.5} \mathrm{CoO}_{3}, \quad \mathrm{La}_{0.75} \mathrm{Sr}_{0.25} \mathrm{MnO}_{3}$, $\mathrm{Ba}_{0.5} \mathrm{Sr}_{0.5} \mathrm{Co}_{0.75} \mathrm{Fe}_{0.25} \mathrm{O}_{3}$, and $\mathrm{La}_{0.625} \mathrm{Sr}_{0.375} \mathrm{Co}_{0.25} \mathrm{Fe}_{0.75} \mathrm{O}_{3}$ compositions. A weighted average $E_{\text {vac }}$ 
data is built for complex perovskites, which contain different groups of oxygen atoms that are coordinated to distinct metal atoms. In-house developed scripts have been used to handle the preparation of VASP calculation input files and to confirm the convergence in all of the completed DFT calculations. Thus, $E_{\text {vac }}$ data has been obtained only for the successfully optimized compositions.

\section{REFERENCES}

(1) Kresse, G.; Furthmüller, J. Efficiency of Ab-Initio Total Energy Calculations for Metals and Semiconductors Using a Plane-Wave Basis Set. Comput. Mater. Sci. 1996, 6, 15-50.

(2) Kresse, G.; Furthmüller, J. Efficient Iterative Schemes for Ab Initio Total-Energy Calculations Using a Plane-Wave Basis Set. Phys. Rev. B 1996, 54, 11169-11186.

(3) Kresse, G.; Hafner, J. Ab Initio Molecular Dynamics for Open-Shell Transition Metals. Phys. Rev. B 1993, 48, 13115-13118.

(4) Blöchl, P. E. Projector Augmented-Wave Method. Phys. Rev. B 1994, 50, 17953-17979.

(5) Kresse, G.; Joubert, D. From Ultrasoft Pseudopotentials to the Projector Augmented-Wave Method. Phys. Rev. B 1999, 59, 1758-1775.

(6) Perdew, J. P.; Burke, K.; Ernzerhof, M. Generalized Gradient Approximation Made Simple. Phys. Rev. Lett. 1996, 77, 3865-3868.

(7) Monkhorst, H. J.; Pack, J. D. Special Points for Brillouin-Zone Integrations. Phys. Rev. B 1976, 13, 5188-5192.

(8) Sebastian, M. T. $\mathrm{ABO}_{3}$ Type Perovskites. In Dielectric Materials for Wireless Communication; Elsevier, 2008, 161-203.

(9) Maiti, D.; Daza, Y. A.; Yung, M. M.; Kuhn, J. N.; Bhethanabotla, V. R. Oxygen Vacancy Formation Characteristics in the Bulk and across Different Surface Terminations of $\mathrm{La}_{(1-}$ ${ }_{x} \mathrm{Sr}_{\mathrm{x}} \mathrm{Fe}_{(1-\mathrm{y})} \mathrm{Co}_{\mathrm{y}} \mathrm{O}_{(3-\delta)}$ Perovskite Oxides for $\mathrm{CO}_{2}$ Conversion. J. Mater. Chem. A 2016, 4, $5137-5148$.

(10) Maiti, D.; Hare, B. J.; Daza, Y. A.; Ramos, A. E.; Kuhn, J. N.; Bhethanabotla, V. R. Earth Abundant Perovskite Oxides for Low Temperature $\mathrm{CO}_{2}$ Conversion. Energy Environ. Sci. 2018, 11, 648-659.

(11) Wang, L.; Maxisch, T.; Ceder, G. Oxidation Energies of Transition Metal Oxides within the GGA+U Framework. Phys. Rev. B - Condens. Matter Mater. Phys. 2006, 73, 195107. 